\title{
Tibeto-Mongol and Chinese Buddhism in Present-day Hohhot, Inner Mongolia: Competition and Interactions
}

\author{
Isabelle Charleux*
}

\begin{abstract}
This chapter investigates the architecture, icons, and activities of two Buddhist monasteries of the Old City of Hohhot, capital of the Inner Mongolia Autonomous Region of China: the (Tibeto-)Mongol Yeke juu (Ch. Dazhao[si]) and the Chinese Buddhist Guanyinsi. In it, I present a global view of the Buddhist revival of the Mongol monasteries of Hohhot since the 1980s, with a focus on the material culture — architecture, cult objects, and "decoration" - of the sites. These monasteries survived in the 1980s and 1990s with many difficulties, and since the 2000s, while the old city was being destroyed, have benefited from an economic boom, the rise of ancient and new forms of religiosities, and the rapid development of tourism. Yet, under the constraints of bureaucratic control, monasteries have limited autonomy and face many difficulties such as isolation from the rest of the Buddhist world, especially that of Tibet and Mongolia, adaptation to modern life and the market economy, and folklorization. The main challenge, however, is sinicization: though monk communities are still ethnically divided, this is no longer the case of lay devotees, the majority of whom are Han Chinese. Considering the fact that the majority of their donors are Han Chinese, how does this affect the physical appearance of these monasteries?

My aim is to analyze the competition between these two monasteries, the religious interactions, influences, and exchanges between Mongol and Chinese Buddhisms in Hohhot (including syncretic tendencies within the monasteries) and the impact that they have had on the city: to wit, how does the city change religion(s) and religion(s) in turn change the city?
\end{abstract}

Keywords: Inner Mongolia, Mongol Buddhism, Chinese Buddhism

\footnotetext{
* I warmly thank Hurelbaatar Ujeed and Uranchimeg Borjigin, who gave me information on Hohhot Buddhism; this article greatly benefited from their help and our interesting discussions. I would also like to thank Ji Zhe and Vincent Goossaert for their insightful suggestions and corrections and Kunsang Namgyal-Lama for our discussions on iconography.
} 
Isabelle Charleux. Authors' own file, not the published version in Sino-Tibetan Buddhism across the Ages, Ester Bianchi \& Shen Weirong (dir.), Brill : Leyde \& Boston (Studies on East Asian Religious, vol. 5), 2021

When I first visited Hohhot (Kökeqota, 1 “the Blue City,” Ch. Huhehaote 呼和浩特), the capital of the Inner Mongolia Autonomous Region (IMAR) in 1993, religious activities were still slow to revive. ${ }^{2}$ Two large Mongol Buddhist monasteries of the Tibetan Gelugpa (dGe lugs pa) tradition, ${ }^{3}$ one small Chinese Buddhist monastery, and one small Daoist monastery as well as a church and a mosque ${ }^{4}$ had re-opened and were operational again. Their ancient architecture was restored with government funds (their buildings and icons, when preserved, were considered local heritage and state property) ${ }^{5}$ but no new building was erected at the time. In the mid2000s, most of the old houses and shops of the Old City ${ }^{6}$ were destroyed to build a "new old city" adapted to modern tourism; in the meanwhile, the space occupied by religious buildings more than doubled, with the construction of huge new halls. Two Buddhist monasteries - the (Tibeto-)Mongol Yeke juu (Ch. Dazhao[si] 大召[寺], “great monastery") and the Chinese Buddhist Guanyinsi 觀音寺 (Avalokiteśvara monastery) —entered into a competition of architectural monumentality. In addition, a new 81.60 meter-high Tibetan-style stūpa, located south of the Guanyinsi and attached to this Chinese Buddhist monastery, was built between 2006 and 2008.

Monumental religious construction multiplied all over China in the 2000s in response to the economic boom, the rise of ancient and new forms of religiosities, and the rapid development of tourism. How does Mongol Buddhism survive in Hohhot, a historically Mongol city now populated by a large majority of Han Chinese residents? Did the cohabitation of different faiths and ethnicities since the city's foundation encourage inter-religious exchanges such as conversions or syncretic tendencies inside its monasteries? My aim is to analyze the

\footnotetext{
${ }^{1}$ I have used Antoine Mostaert's system to transcribe the Uyghur-Mongolian script, but I have replaced "č" and "y" with a plain "c" and "j."

${ }^{2}$ In keeping with the scope of the "reform and opening-up" policy of Deng Xiaoping, article 36 of the Constitution of the People's Republic of China of 1982 guarantees freedom of religious belief (in the five officially sanctioned religions).

${ }^{3}$ They all are male monasteries; no nunneries ever developed in Inner Mongolia.

${ }^{4}$ As of the 2010s, Hohhot is home to ten mosques and several Catholic and Protestant churches. Since the eighteenth century, Hohhot has had a significant population of Chinese Muslims (Huizu 回族), numbering onehundred thousand in the 2010s, plus a few Mongol Muslims. Shamanism and popular cults such as oboya worship, though not acknowledged as being "religions" by the Chinese state, are tolerated because they are seen as folk ethnic practices, but there are apparently no shamans in Hohhot. This paper does not deal with unofficial religious communities housed in private lodgings.

${ }^{5}$ On the process of reopening a monastery, see MacInnis, Religion in China Today, 17-18. Monasteries are under the authority of the Buddhist Association, of administrations in charge of the protection of cultural heritage (the Archaeology Department of a museum, the wenwu baohu danwei 文物保護單位 [Heritage protection unit]), of the Bureau of Urbanism, and of the local authorities; they must negotiate with these administrations to have any restoration or construction approved. This can lead to potential conflicts over the control of the sites and over differing conceptions of their use (see an example of such a conflict in Charleux, "The Reconstruction of Buddhist Monasteries," 14). In China, local authorities use heritage as a strategy to develop the economies of the "minority ethnic groups" (shaoshu minzu 少數民族). Ethno-religious tourism is also promoted in Tibet; the government uses the UNESCO heritage convention to classify Tibetan monasteries as cultural sites, accelerating their "touristification." The patrimonialization of religious places of shaoshu minzu leads to tensions between the faithful and visitors, as is the case at the Tibetan monastery of Labrang (Gansu). (Shepherd, "UNESCO and the Politics of Cultural Heritage in Tibet;" Shepherd and Yu, Heritage Management, Tourism, and Governance in China; Maags and Svensson, Chinese Heritage in the Making).

${ }^{6}$ The Old City is a now small area north of Jade Spring district (Yuquanqu 玉泉區), bordered by the Huimin district 回民區 to the north and Ordos street (E'erduosi jie 鄂爾多斯街) to the south. “Hohhot” does not designate here the whole municipality ( $s h i$ 市) but the urban area only, which is composed of four districts ( $q u$ 區): Yuquan, Huimin, Saihan 賽罕, and Xincheng 新城.
} 
Isabelle Charleux. Authors' own file, not the published version in Sino-Tibetan Buddhism across the Ages, Ester Bianchi \& Shen Weirong (dir.), Brill : Leyde \& Boston (Studies on East Asian Religious, vol. 5), 2021

competition between the Buddhist monasteries, as well as the religious interactions, dialogues, crossed influences, and exchanges, or tensions and conflicts, between the clerical and lay members of the different Buddhist communities and the impact that they have had on the city, notably on urbanism and architecture. How does the city impact religion(s) and religion(s) in turn impact the city? Is there a peaceful sharing of urban space, and are there shared sacred sites? I attempt to address these questions by focusing on the material culture of the monasteries - architecture, objects of cult, and "decoration."7

If the monastic communities are still ethnically divided between Mongols and the Han, that is not the case of the lay devotees anymore: Mongol and Chinese Buddhist monasteries are frequented and sponsored by a majority of Han Chinese adherents. Mongols primarily worship at Mongol Buddhist monasteries, but many of them are attracted by Chinese Buddhism and frequent the Guanyinsi. Has religion then ceased to be a cultural marker? Considering the fact that the majority of their donors are Han Chinese, and also that many Han devotees are especially interested in Tibetan Buddhism, does it entail a certain homogenization of the architecture and icons of the Mongol and Chinese Buddhist monasteries? I will first give some precise details about the degree of ethnic mixing in this "border city" and then describe the Buddhist landscape of the Old City.

\section{Mongols, Han..., or Inner Mongols?}

The tumultuous events that unfolded in Inner Mongolia during the twentieth century disrupted Mongol society, politics, and religions, with a combination of modernization, anti-clericalism, secularization, Han immigration, and persecution, especially during the Cultural Revolution (1966-1976). This has led to a major loss of Mongol language and culture. Of the $8.56 \%$ of Hohhot city inhabitants who are ethnically Mongol (as of 2010) ${ }^{8}$ - less in the Old City ${ }^{9}$ - it is estimated that only 20\% can speak Mongolian. The frontier between Mongols and the Han has become more and more porous, with many intermarriages, ${ }^{10}$ and Han Chinese people have declared themselves as Mongols to obtain certain privileges. ${ }^{11}$ Anthropologists argue that,

\footnotetext{
${ }^{7}$ The contemporary Buddhist revival is not my main field of research, and this chapter is not based on a deep ethnographic study of Buddhist monks and lay devotees, but rather on the evolution of Hohhot's urbanism and religious architecture that I observed over the course of twenty years of fieldwork and during discussions with Hohhot Mongol and Han Chinese residents.

${ }^{8}$ Wikipedia article on “Hohhot," quoting “Di liuci quanguo renkou pucha”第六次全國人口普查 [Sixth National Population Census of the People's Republic of China], https://en.wikipedia.org/wiki/Hohhot, accessed February 23, 2021.

${ }^{9}$ According to Jankowiak (Sex, Death and Hierarchy in a Chinese City, 10, table 2.1), Mongols made up only 5.6\% in Yuquan district in the 1980s. Many Mongols from other banners and leagues of the IMAR were forcibly settled in the new districts of Hohhot in the 1950s; consequently, the Mongol population is higher than it was in 1949.

${ }^{10}$ The registered Mongols of the IMAR include many people of mixed race-15\% of married Mongols have nonMongol spouses, and 310,000 people changed their "ethnic group" (minzu 民族) to that of Mongol in 1982 (see Khan, "Who Are the Mongols?," 142, 145 n. 35). For Hohhot it is estimated that $54 \%$ of the Mongol residents married Han Chinese people in the early 1990s (Bilik, "The Mongol-Han Relations," 87-88).

${ }^{11}$ This was especially true in the 1980s, when certain material advantages, such as the authorization to have more than one child, greater political representation in their autonomous areas, and privileged access to higher education and official positions, were given to minorities. On these shifting and imagined ethnic boundaries in Hohhot, see Bilik, "The Mongol-Han Relations."
} 
Isabelle Charleux. Authors' own file, not the published version in Sino-Tibetan Buddhism across the Ages, Ester Bianchi \& Shen Weirong (dir.), Brill : Leyde \& Boston (Studies on East Asian Religious, vol. 5), 2021

particularly in cities, a new hybrid Inner Mongol identity (Neimeng ren 内蒙人) has emerged with no foundation in ethnicity, but instead based on shared places and experiences. ${ }^{12}$ Most of the former cultural markers such as food, dwelling, wearing of traditional costume, language, and, as we will see, religion have been eroded (meaning that Mongols are adopting Han culture but also that Han people are appropriating Mongol markers).

If the difference between a Han and an urban Mongol is often not easily perceivable for an outsider, from an emic point of view, Mongols (especially Mongolian-speaking Mongols) are usually proud of their Mongol identity. They prefer to mix socially with other Mongols and do perceive themselves as different from the Han Chinese, even if their Mongol qualities are often no more than "nostalgic ties with the past and emotionalized ethnicity." 13 The terrible purges that targeted Mongols during the Cultural Revolution, ${ }^{14}$ the following degradation of relations between the two communities, and eventually the Mongols' massive "nationalist" protests in the 1980s are still remembered vividly, contributing to the widening, if not, in some cases, the creation, of the gap between the two communities. Furthermore, distinctions between Mongol groups are enhanced in the capital city, where Mongols come from all parts of Inner Mongolia to work and study. Each group has a different dialect, history, and set of customs. The historically settled group, the Tümeds, are deeply sinicized, and the majority of them does not speak Mongolian anymore. They started to adopt Chinese cults and customs in the eighteenth century, notably ancestors' cults (for instance they celebrate qingming jie 清明節 and burn paper objects for their dead). The Tümed officials working for the Qing (1644-1911) government had a Temple of Literature, or Confucius temple (Tumote wenmiao 土默特文廟, Kongzimiao 孔子廟), built in $1724 .{ }^{15}$ During the twentieth century, because many of their leaders rose to high government, party, and military positions in the IMAR, ${ }^{16}$ the Tümeds usually had a more comfortable life than other Mongol groups. They suffered the fiercest persecutions during the Cultural Revolution and received more advantages than the other groups as compensation. ${ }^{17}$ Similarly, the Han Chinese are not a monolithic "nationality/ethnicity" (minzu 民族); they distinguish themselves by their "level of nativeness" (ancient settlers versus recent migrants) ${ }^{18}$ and feel themselves to be very different from southern Chinese people. They suffer from a second-class status and have to "fight for a rightful place in their host minority region." 19

\footnotetext{
${ }^{12}$ For Jankowiak (Sex, Death and Hierarchy in a Chinese City), differences are concentrated around minor markers while similarities abound over fundamental issues in ethics, status, life goals, and worldview. Jankowiak (ibid.), Bulag ("Alter/native Mongolian Identity”), and Billé ("Cooking the Mongols/Feeding the Han”) have stressed the irrelevance of considering only ethnic distinctions between the Han and Mongols in Inner Mongolia.

${ }^{13}$ Bilik, "The Mongol-Han Relations," 72.

${ }^{14}$ It is estimated that more than half of the adult population was "purged" (arrested, imprisoned, tortured, and/or killed). More than one-hundred thousand died either directly or indirectly from wounds inflicted during the Cultural Revolution, and between 350,000 and 500,000 were arrested.

${ }^{15}$ A small building from the Temple of Literature was preserved inside the Tümed school (Tumote xuexiao土默 特學校) and serves as a museum of Ulanhu (1906-1988) and Tümed officials, of the Tümed school itself, and of the communist period in Hohhot.

${ }^{16}$ Ulanhu, founding chairman and main political figure of the IMAR, was a Tümed Mongol.

${ }^{17}$ They provided leadership to the Inner Mongol communist movement and were particularly targeted when the heads of the organization fell (Bulag, "Alter/native Mongolian Identity," 269, 273).

${ }^{18}$ Billé, "Cooking the Mongols/Feeding the Han," 207.

${ }^{19}$ Bulag, "Alter/native Mongolian Identity," 278.
} 
Isabelle Charleux. Authors' own file, not the published version in Sino-Tibetan Buddhism across the Ages, Ester Bianchi \& Shen Weirong (dir.), Brill : Leyde \& Boston (Studies on East Asian Religious, vol. 5), 2021

Although these ethnic terms are arbitrary social constructions ${ }^{20}$ and frontiers between them are permeable and constantly moving, they remain important from an emic point of view. Ethnic boundaries are socially and politically constructed categories but are not static, and Mongols themselves participate in these constructions and reinforce them. The anthropologist U. Bulag refers to this as "resistance within collaboration." 21

\section{The Hohhot Buddhist Landscape in the Twentieth Century}

This paper focuses on the "Old City" previously known as Guihuacheng 歸化城 ("Return to Civilization"), founded by Altan Khan (1507/8-1582) in 1572 as a palatial and Buddhist center, which later evolved into a commercial center. ${ }^{22}$ There was no "ethnic enclave" inside the Old City; the Mongols and Han Chinese had resided side by side since the city's foundation. ${ }^{23}$ Most of the religious buildings were, and still are, concentrated in this old heart of the city. North of it is the "Muslim district" (Huiminqu). In the early twentieth century, the Old City and the Muslim district held eleven Mongol Buddhist monasteries, one Chinese Buddhist monastery, twelve to nineteen Chinese temples, six mosques, one Catholic church, and five Protestant churches. ${ }^{24}$

\footnotetext{
${ }^{20}$ On the artificial construction of minzu by the Chinese state, see Gladney, "Representing Nationality in China;" and Atwood, "National Questions and National Answers."

${ }^{21}$ Bulag, "Models and Moralities." In his book Collaborative Nationalism (25), Bulag challenges old conceptions of majority-minority relations and argues that Mongols both resist the state's ideology and collaborate with the Chinese system and in the representation of Mongol culture.

${ }^{22}$ For a description of the Old City, its location and history, see Hyer, "An Historical Sketch of Köke-Khota;" for its plan and modern development, see Gaubatz, Beyond the Great Wall, 62-69; for its monasteries, see Charleux Temples et monastères de Mongolie-Intérieure, chapters 1 and 2, and CD-rom: "Bannières Tümed de Kökeqota;" and Bao, Mongoru ni okeru toshi kenchikushi kenkyū, 148-65.

${ }^{23}$ In the early twentieth century, half of Guihua's population was Chinese, the other half being Mongols and a few "Muslims" (a majority of whom were Chinese, i.e. Hui). The Old City contained about twenty-thousand inhabitants: a 1908 census counted 3,117 families in the eighty-one streets of the Old City (Zheng \& Zheng, Guisui xian zhi, 184).

${ }^{24}$ Zheng \& Zheng, Guisui xian zhi, 222-28, also 304-6. Between 1735 and 1739, a Qing garrison named Suiyuan 綏遠 (City for the Pacification of Remote Areas) was built three kilometers north-east of Hohhot to organize military campaigns against the Junghars, and the two cities were then respectively known as Old and New. Hohhot/Guihua and Suiyuan were united to form one city during the Republican period. Of the twenty Chinese temples and monasteries of Suiyuan, only one (a Daoist monastery) was revived under the name Taiqinggong 太 清宫.
} 


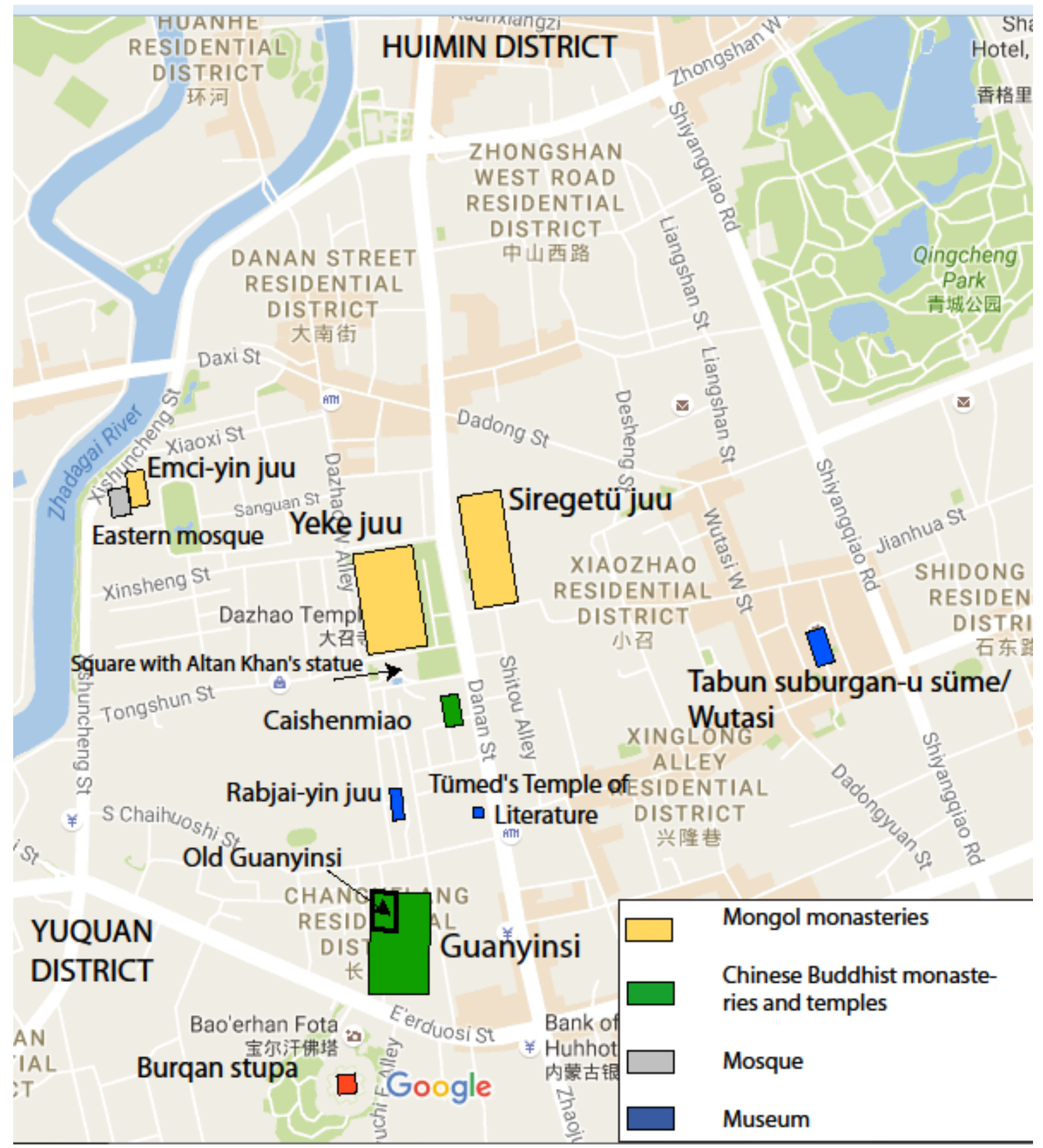

Fig. 1. Map of the Old City of Hohhot. (C) Isabelle Charleux (from Google map) 
Isabelle Charleux. Authors' own file, not the published version in Sino-Tibetan Buddhism across the Ages, Ester Bianchi \& Shen Weirong (dir.), Brill : Leyde \& Boston (Studies on East Asian Religious, vol. 5), 2021

Mongol Buddhism, which had flourished in Hohhot since the foundation of the city in 1572, enjoyed certain privileges after $1947 .{ }^{25}$ In the early communist period, because "ethnic minorities" received preferential treatment, ${ }^{26}$ Mongol Buddhist monasteries fared relatively well in comparison with Chinese temples; their three main monasteries-Yeke juu (Dazhao), ${ }^{27}$ Siregetü juu (Ch. Xilituzhao 席力圖召) ${ }^{28}$ and Baya juu (Ch. Xiaozhao 小召) ${ }^{29}$ —stayed open up during the Cultural Revolution, while all the Chinese temples were closed, destroyed, or abandoned (in 1956-1958) (fig. 1). During the Cultural Revolution, with the exception of the main assembly hall of the Yeke juu, all of the temples were emptied of their statues, furniture, texts, and paraphernalia.

In the 1980s, Mongol monasteries continued to receive special treatment, as a "compensation" for the harsh persecutions of Mongols during the Cultural Revolution. ${ }^{30}$ Although more than 90\% of its inhabitants were now Han Chinese, Hohhot's main religion was declared to be Tibeto-Mongol Buddhism. From 1980 on, the Eleventh reincarnation of the Siregetï quturtu, Jamsu (1943-2014), then the most important religious personality of Inner Mongolia, ${ }^{31}$ was nominated to be the head of the Buddhist Association of Hohhot (Huhehaote shi fojiao xiehui 呼和浩特市佛教協會). ${ }^{32}$ He therefore controlled both Mongol and Chinese Buddhism. ${ }^{33}$ During his lifetime, he established the headquarters of the Buddhist Association in his old residence within the Siregetï juu, which naturally became the most active and wealthiest

25 The IMAR was established in 1947, two years before the creation of the PRC.

${ }^{26}$ Since 1978, the religious policy for minorities has differed from the policy for the Han Chinese because it has been admitted that "the majority (of minority people) believes in religion," and that "the questions of religion and ethnicity are frequently intermingled" (MacInnis, Religion in China Today, 21, also 51-55; text quoted in Yang, "Nei Menggu zangchuan fojiao jinkuang zhi tantao," 3).

${ }^{27}$ The Yeke juu, founded by Altan Khan in 1579-1580, was the main royal, and under the Qing, imperial monastery of Hohhot. It houses a famous statue known as the Silver Juu (Tib. Jo bo) modelled on the Jo bo Śākyamuni of the Jo khang temple of Lhasa. On its history, see Charleux, Temples et monastères de MongolieIntérieure, CD-rom: "Yeke juu." A clothes factory occupied its building until 1967, after which the monastery remained closed and well-protected during the Cultural Revolution.

${ }^{28}$ The second largest monastery of Hohhot, the Siregetiu juu was founded in the 1570s and rebuilt in 1585-1586; it later became the residence of the Siregetü quturtu. On its history, see Charleux, Temples et monastères de Mongolie-Intérieure, CD-rom: "Siregetü juu."

${ }^{29}$ It was partially destroyed during the Cultural Revolution, then occupied by a school, and progressively fell into ruin. Only its ceremonial archway has been preserved.

${ }^{30}$ On the revival of Mongol Buddhism in Inner Mongolia in the 1990s, see Charleux, "The Reconstruction of Buddhist Monasteries."

${ }^{31}$ A Tibetan of Eastern Tibet, he was married and had children. Enthroned as a reincarnated lama in 1956, he was appointed executive director of the Inner Mongolia Branch of the Buddhist Association of China. He was arrested during the Cultural Revolution and rehabilitated in 1970. From 1973 to 1975, he became famous for his practice of medicine and cured many patients at the Sino-Mongol hospital of Inner Mongolia. After the Cultural Revolution, Jamsu was appointed president of the Buddhist Association of Hohhot (1980), general secretary of the Buddhist Association of the IMAR (1982), and founded the Buddhist School of Inner Mongolia, over which he presided. See his autobiography: Zhamusu, "Wo de huofo shengya," and "Nei Menggu Huhehaote Xilituzhao huofo jianlüe." ${ }^{32}$ This was a branch of the Buddhist Association of the IMAR dependent on the Religious Affairs Bureau. The Buddhist Association controls religious activities and the application of official policy. It was later moved to the Yeke juu and again, in the 2010s, to the Emci-yin juu. On the different government agencies which control religious matters, their bureaucratic hierarchy, and the management committee of monasteries, see "Document 19" in MacInnis, Religion in China Today, 18; and Stockwell, Religion in China Today.

${ }^{33}$ Ever since the first National and Local Religious Associations were founded in the early years of the Republic, there has been no separate Buddhist association for Chinese Buddhism and for Tibeto-Mongol Buddhism. 
monastery in Hohhot and its whole region and the center of the revitalization of Mongol Buddhism. With the RMB 4 million that the municipality of Hohhot allocated to him between 1982 to 1989, the Siregetü quturtu had a dozen Mongol monasteries restored and returned to lama communities ${ }^{34}$ in and around Hohhot. ${ }^{35}$

The, at the time very small, Guanyinsi and Taiqinggong were given back to Chinese Buddhist and Daoist communities, respectively, both of which counted just a few monks and could not organize major rituals. No Chinese "popular" temple was revived at that time. Given that devotees of Han Chinese Buddhism were in need of temples to organize their activities, the local Chinese Jushilin 居士林 (Buddhist lay association) ${ }^{36}$ rented a small chapel in the Siregetiu juu between 1995 to 1998 and had it transformed into a Guanyin shrine after miracles - an image of Guanyin produced miraculous light and a butterfly appeared in winter-occurred there. ${ }^{37}$ A Daoist master (daoshi 道士) also gave teachings in the Siregetii juu. In the 1990s, Chinese Buddhist monks (heshang 和尚), lay Buddhists of the Guanyinsi, and Daoist priests of the Taiqinggong were all invited to participate in great rituals in the Siregetü juu (fig. 2).

\footnotetext{
${ }^{34}$ After 1979, lamas were released from prisons and labor camps and rehabilitated; many of them had by then taken wives.

${ }^{35}$ Charleux, "The Reconstruction of Buddhist Monasteries," 16.

${ }^{36}$ Lay Buddhists have made a conscious commitment by going through the Triple Refuge ceremony; like monks and nuns they receive a "Dharma name" and thus enter the Buddhist "family." This is recorded on a certificate (guiyi zheng 阪依證), a kind of Buddhist identification card with the individual's photograph, which allows a jushi to visit a monastery of their province without paying the entrance fee charged to tourists. Ordinary monks and reincarnate lamas also have certificates.

${ }^{37}$ The Guanyin shrine was later turned into a shop.
} 


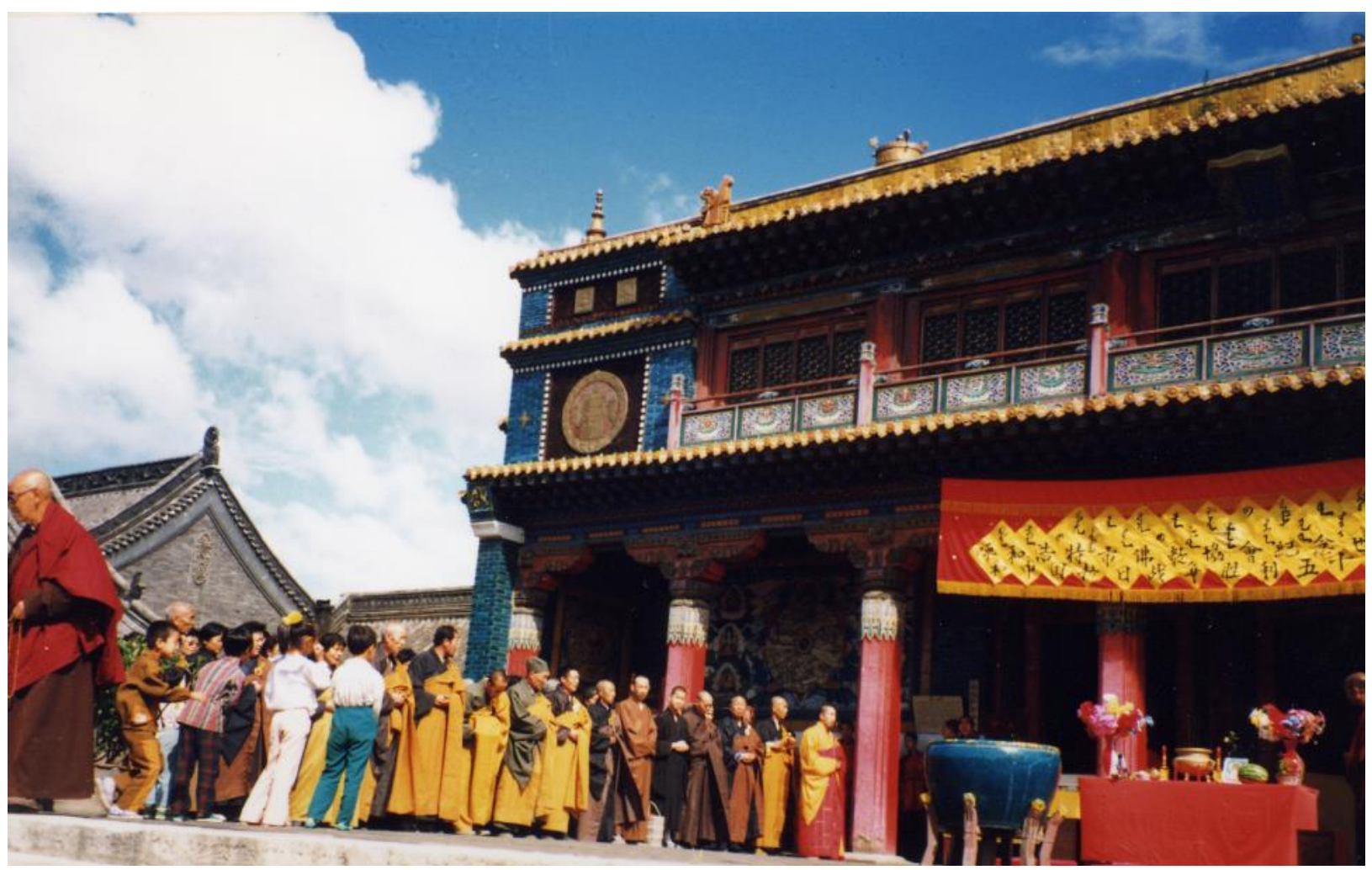

Fig. 2. Chinese Buddhist monks attending a main ritual (together with Buddhist jushis and Daoist priests) performed by Mongol lamas in the Siregetü juu, summer 1995. () Isabelle Charleux, 1995

The religious revival was limited due to the impact of bureaucratic controls and stateregulated structures, which put a bridle on the monasteries and thereby reduced their autonomy. They had (and still have) to be financially self-sufficient - economic autonomy of a monastery was a condition for its reopening. Hence, they need to attract both worshipers and tourists because, having lost their landed properties, their main sources of income are tourism and donations. ${ }^{38}$ The two main Mongol monasteries sell entrance tickets for tourists (the cost of which was RMB 35 at the Yeke juu and Siregetü juu in 2016), but the Guanyinsi does not.

In the 1980s and 1990s, both Chinese and Mongol monasteries in Hohhot, as did Buddhist monasteries elsewhere in China, suffered from the low educational level of the clergy because of the scarcity and old age of Buddhist masters, ${ }^{39}$ the professionalization of

\footnotetext{
${ }^{38}$ Monastery income includes entrance tickets, government support, and "donations," which are either gifts proper (given in front of icons, during collective rituals, or collected for the construction of a new building) or remunerations for rituals on individual requests. Donations can be invested in businesses, the profits of which are used to sponsor specific festivals. Monasteries also run or rent hostelries and shops selling religious items (incense, wind-horse flags, Buddhist music, icons, etc.), souvenirs, and Tibetan medicine.

${ }^{39}$ For an overview of Buddhism in China in the twentieth and twenty-first centuries, with a focus on male clergy, see Birnbaum, "Buddhist China at the Century's Turn."
} 
Isabelle Charleux. Authors' own file, not the published version in Sino-Tibetan Buddhism across the Ages, Ester Bianchi \& Shen Weirong (dir.), Brill : Leyde \& Boston (Studies on East Asian Religious, vol. 5), 2021

monkhood, ${ }^{40}$ and the short duration of monastic studies. ${ }^{41}$ With monasteries being turned into profit-based organizations, monks began to spend most of their time selling entrance tickets and keeping watch on the halls. In addition, Mongol monasteries are isolated from the rest of the Tibetan Buddhist world, i.e. Tibet and Mongolia. It was commonly said in the 1990s and 2000s that Mongol monks were ignorant, depraved, disrespectful, and arrogant. While in mainland China, lamas from Tibet are often believed to be surrounded with an aura of holiness and to be more "authentic" than Chinese heshangs, the Mongol lamas of Hohhot are accused of immoral behavior, of not respecting their vows (few lamas are celibate; the great majority are actually novices who did not take the precepts of gelüng ${ }^{42}$ ), and of being ignorant and not able to understand the meanings of sütras. ${ }^{43}$ Although monastic disciple in Mongol monasteries is stricter in the 2010s than it was in the 1990s and monks are better educated, there are still contrasting opinions about their reputation.

\section{The Hohhot Buddhist Landscape in the Twenty-First Century}

After the massive restorations of old Mongol monasteries that occurred during the mid-1990s, the local and regional administrations subsidies were practically phased out or reduced to occasional allowances. In the 2000s, in the context of a strong demographic and urban expansion (from 110,000 inhabitants in 1949 to almost 2 million in 2010), ongoing real estate speculation and promotion of tourism, ${ }^{44}$ the authorities of Hohhot decided to "clean," that is to say, to completely destroy the old city (mostly from 2002 to 2006) save a few "remarkable" buildings. This in spite of the fact that Hohhot was included in 1987 among the "national level famous historic and cultural cities" of China. ${ }^{45}$ The older districts of large cities were similarly destroyed all over China, starting with Beijing and Tianjin, to build modern housing and a few mock old-style streets for tourism purposes. ${ }^{46}$ In Hohhot, a new "old district" was built around

\footnotetext{
${ }^{40}$ On the reasons why Mongols become monks, monks' salary, and extra earnings, see Erhimbayar, "Mongolian Buddhist Monasteries," 193-94. The Religious Affairs Bureau must give its agreement when a novice applies to join a monastery. The quota of monks is fixed per monastery, and it is not easy to enter a monastery located in a large city because of limitations imposed on migrating to towns.

${ }^{41}$ In the past, novices used to enter a Mongol monastery at six or seven years old. The duration of monastic training was about ten to twelve years. A novice who enters the monastery at his majority will not be able to assimilate the huge corpus of scriptures or to learn complex rituals. Moreover, those who enter as adults are too used to secular life to accept monastic discipline. Today, one has to be eighteen years old to enter monkhood (and twenty to be fully ordained); as a result, the monastery is incapable of forcing a monk to obey its discipline, and monks are free to quit monkhood whenever they like. Nevertheless, in Inner Mongolia, as in Tibet, there is a tolerance for younger novices: the Siregetü juu and the Yeke juu accept twelve- or thirteen-year-old novices.

42 Tib. dge slongs, a fully ordained monk who observes the 253 monastic precepts.

${ }^{43}$ Fieldwork notes between 1995 and 2016. On pessimistic attitudes towards the loss of expertise and ignorance of the clergy in the 2000s and the superficiality of the faith of devotees, see Mair, "Cultures of Belief."

${ }^{44}$ The tourist industry throughout China's border regions is part of a state's ethnic management policies and contributes to the shaping of ethic identities in China.

${ }^{45}$ Up until the late 1990s, Hohhot preserved one of the most interesting urban complexes of North China (Charleux, "De la ville bleue à la métropole grise"). By contrast, excepting the Old City, twenty-first century Hohhot looks like any Chinese city — even though some buildings are built with "Mongol characteristics," such as a yurt-shaped roof, or Central Asian characteristics, domes and green colors, in the Muslim district.

${ }^{46}$ In China, the theoretically virtuous alliance between tourism and heritage, following Unesco's recommendations, often leads to the entire rebuilding of "protected" sites. The inscription of a monument on the heritage lists does not guarantee its preservation or its commercial transformation. Voices are being raised against the commodification of tangible heritage, especially by local communities, and the role of media and social networks can be crucial. Lui Tam gives an example of heated debate over a Beijing temple inscribed on the list of municipal
} 
the Yeke juu with shops and restaurants for tourists (fig. 3). ${ }^{47}$ Altan Khan, one of the heroes of “the unity of nationalities" (minzu tuanjie 民族團結) and “multiculturalism" (duoyuan wenhua 多元文化) of present-day China, ${ }^{48}$ was honored through public statuary. In the new square in front of the Yeke juu, his large statue faces east — looking toward Beijing (fig. 4).

To promote tourism, the Hohhot municipality massively invested in monumental temple construction at the same time that it was rebuilding the Old City. In 2006, it paid more than RMB 20 million (about USD 2 million) to enlarge the Guanyinsi and more than RMB 10 million (USD 1 million) to enlarge the Yeke juu ${ }^{49}$ - to date the government has supported the cost of repairs to ancient religious buildings protected as "cultural heritage" but not the construction of new ones. This project was presented as an "investment" for touristic development; the two monasteries had been considered too small when compared with the expected development of the tourist industry. While most of the religious buildings of Hohhot are only of a modest scale, the Yeke juu and the Guanyinsi rival each other in terms of monumental construction (Table 1).

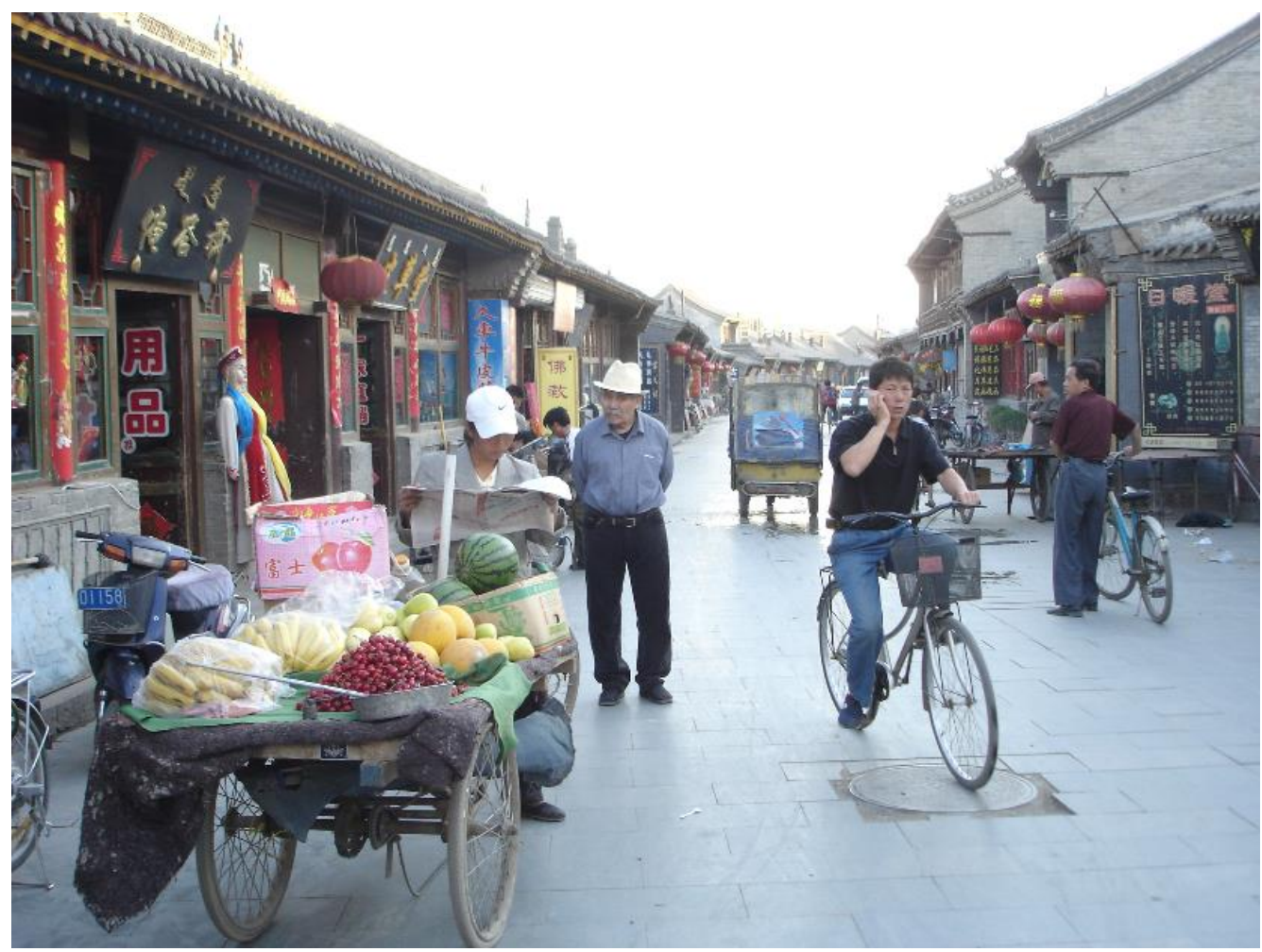

Fig. 3. Rebuilt Tongshun street. (C) M.-D. Even, 2006

heritage sites, a designation that has not prevented its transformation into a hotel, restaurant, and art gallery ("The Revitalization of Zhizhu Temple Policies, Actors, Debates").

${ }^{47}$ On the destruction of the Old City, see Charleux, "De la ville bleue à la métropole grise." On the urban transformations of Hohhot during the twentieth century, see Gaubatz, Beyond the Great Wall, chapter 10; and Bao, Mongoru ni okeru toshi kenchikushi kenkyū.

${ }^{48}$ Altan Khan signed a peace treaty with the Ming in 1571 after years of border conflicts.

49 "Hushi zongtouzi 3000 yu wan yuan kuojian Dazhao Guanyinmiao;" "Huhehaote Dazhaosi yinlai lüyou gaofengri jiedai youke 600 ren." The Yeke juu and the Siregetü juu exhibit the sign "National tourist attraction" (Guojia ji lüyou jingqu 國家級旅游景區) in both English and Chinese. 


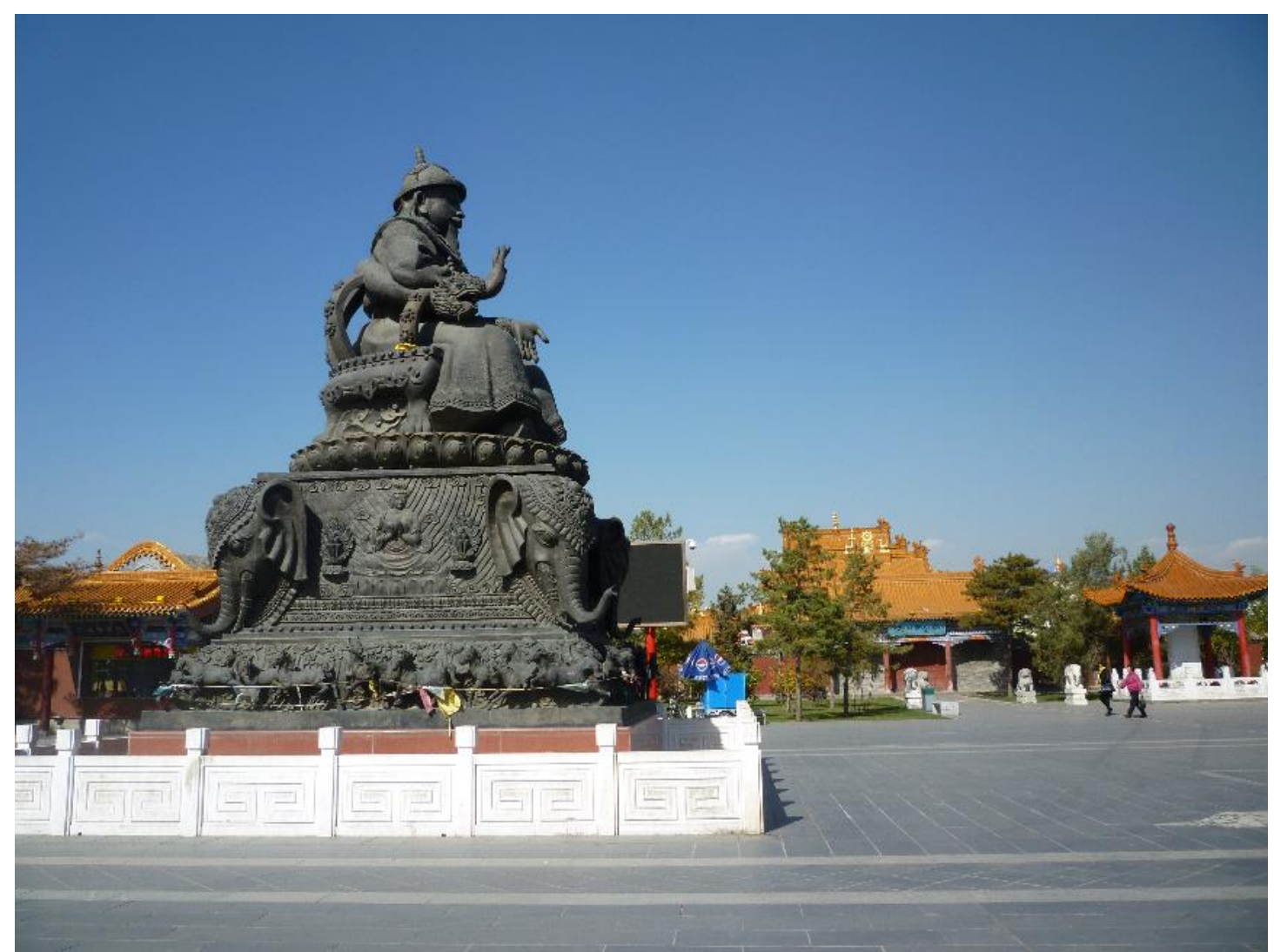

Fig. 4. Altan Khan square, with the large statue of Altan Khan and the main entrance of the Yeke juu (see from the south). (C) Isabelle Charleux, 2012

As of 2016, the active religious institutions in the Old City are the two large Mongol monasteries, Yeke juu and Siregetui juu, along with the small Emci-yin juu (Ch. Naimuqizhao 乃穆其召 or Longshousi 隆壽寺); a Chinese Buddhist monastery-Guanyinsi; a Chinese temple: Caishenmiao 財神廟, a God of Wealth temple; and the southern mosque, Qingzhen nansi 清真大寺, adjacent to the Emci-yin juu (fig. 1). The Old City is thus divided between Chinese Buddhism to the south and Mongol Buddhism in the center. The Muslim district is located just north of the old citadel around the old preserved Qingzhen mosque 清真大寺; the main Catholic church is also located in this district. Other religious buildings in the area were preserved, renovated, and reallocated as museums, such as the Tabun suburyan-u süme (Ch. Wutasi 五塔寺), or were dismantled and moved to the outdoor museum of Ming and Qing architecture in the suburbs (Ming Qing gujianzhu bowuguan 明清古建築博物館). ${ }^{50}$ Others are still occupied by public or private establishments.

\footnotetext{
${ }^{50}$ Such as the Guandimiao 關帝廟 of Xiaodong street 小東街.
} 
Isabelle Charleux. Authors' own file, not the published version in Sino-Tibetan Buddhism across the Ages, Ester Bianchi \& Shen Weirong (dir.), Brill : Leyde \& Boston (Studies on East Asian Religious, vol. 5), 2021

Table 1. Comparison between Yeke juu and Guanyinsi in 2016

\begin{tabular}{|l|l|l|}
\hline & Yeke juu (Dazhaosi) & \multicolumn{1}{|c|}{ Guanyinsi } \\
\hline $\begin{array}{l}\text { Surface area of the new } \\
\text { buildings }\end{array}$ & 3,300 square metres & 5,000 square metres \\
\hline Tallest building & $13 \mathrm{~m}$. high Jade Buddha hall & $\begin{array}{l}36.45 \mathrm{~m} \text {. high Main Buddha hall } \\
+81.60 \mathrm{~m} \text {. high Burqan stūpa }\end{array}$ \\
\hline Cost of new construction & $10+20$ million Yuan & $20+30$ million Yuan \\
\hline Number of visitors a year & 220,000 & 300,000 \\
\hline $\begin{array}{l}\text { Number of major festivals } \\
\text { per year }\end{array}$ & 13 & $8-10$ \\
\hline $\begin{array}{l}\text { Number of monks and lay } \\
\text { Buddhists }\end{array}$ & 60 Mongol lamas & $\begin{array}{l}20 \text { Chinese heshangs }+ \text { many } \\
\text { lay Buddhists }\end{array}$ \\
\hline
\end{tabular}

\section{The Mongol Buddhist Monasteries}

The Yeke juu, which in the 2000s had become the main monastery of Hohhot as the fortunes of the Siregetui juu declined, has as of 2016 more than sixty monks and novices, about eight of whom are married. The abbot (Mo. jasay blama) of Yeke juu, Galsangsirab (Ch. name Zhao Jiujiu 趙九九), a Tümed, elected as abbot in 1989, is also vice-president of the Buddhist Association of China, president of the Buddhist Association of Inner Mongolia, and vicepresident of the Inner Mongolia Buddhist School (Nei Menggu fojiao xuexiao xiaozhang 內蒙 古佛教學校校長). ${ }^{51}$

Comparatively, the Siregetï juu attracts few tourists and worshippers and receives far fewer donations than the Yeke juu. It now has only about thirty monks, as the others "went back home" (returned to lay life) in the 2000s. The monks of the Yeke juu and Siregetiu juu come from all over Inner Mongolia, and very few of them have passed the full ordination (Mo. gelüng) ${ }^{52}$

Photographs at the entrance of both monasteries show the abbot or reincarnated lamas receiving religious and political celebrities from China and abroad as evidence that these institutions lie at the center of a political and religious network. Some of these photos are old, one of them even shows a visit of the great reincarnation of Kumbum (sKu 'bum) monastery, the A kya quturtu (who is now living in exile). ${ }^{53}$

The Tibeto-Mongol monasteries of Hohhot have maintained their liturgy in Tibetan and do

\footnotetext{
${ }^{51} \mathrm{He}$ is also a member of the Inner Mongol Political Consultative Conference, Vice-Chairman of Inner Mongolia's Buddhist Association, and deputy to the Hohhot People's Congress (Erhimbayar, "Mongolian Buddhist Monasteries," 195).

${ }^{52}$ The sixty monks of the Yeke juu range in age from fifteen to seventy. Around 2005, about twenty were Tümed and could not speak Mongolian; the others came from Eastern Inner Mongolia. Eight of them were married (Erhimbayar, "Mongolian Buddhist Monasteries," 191, 201).

${ }^{53}$ In 1998, the A kya went into exile in the United States.
} 
Isabelle Charleux. Authors' own file, not the published version in Sino-Tibetan Buddhism across the Ages, Ester Bianchi \& Shen Weirong (dir.), Brill : Leyde \& Boston (Studies on East Asian Religious, vol. 5), 2021

not organize rituals and public teachings in Chinese as several of the monasteries of eastern Inner Mongolia do. ${ }^{54}$ Mongol and Han Chinese devotees come to the Yeke juu for blessings, consecrations of Buddhist images, requests of prayers, and large rituals. Most particularly, they visit and worship the exceedingly charismatic lama, Jin Cheng 金城. ${ }^{55}$ Although he is not a reincarnation, Jin Cheng has become a popular focus of devotion and dwells in the main part of the abbot's residence. During the lunar New Year, he receives devotees who queue for blessings, sütra recitations, and cures and to bring him offerings. In addition to Jin Cheng, devout Mongols and Han Chinese also go to the countryside to worship the "barefoot lama." 56 It must be noted that there are no more reincarnated lamas in Hohhot. The Siregetui quturtu passed away in 2014, and his reincarnation has not been found yet (a subscription is being taken in the Siregetï juu to build his funerary stüpa). ${ }^{57}$

The Yeke juu receives large revenues from international and domestic tourism. While donations, especially on the occasion of a festival, and fundraising toward new buildings do allow the Yeke juu to increase its revenue, entrance fees represent a more regular income. In 2008, it received 219,000 visitors (tourists from China and abroad, plus lay Buddhists from outside of the IMAR, who pay the entrance fee). Without counting local devotees, that is an average of six hundred persons a day. ${ }^{58}$ The monastery organizes four rituals every month and thirteen festivals every year (Table 1). ${ }^{59}$ The festivals are crowded with several thousand people and large donations are made on these occasions. The main festival, that of the lunar New Year, is performed from the $8^{\text {th }}$ to the $15^{\text {th }}$ of the first month and includes a very costly cam (masked ritual dance). During this time of year, the entire religious life of the city seems to be concentrated there ${ }^{60}$ During the one-week festival (from the $14^{\text {th }}$ to the $20^{\text {th }}$ day of the eighth lunar month), 350 monks from across the Hohhot region gather in the Yeke juu, read sütras day and night for the happiness of all the living beings, and perform a circumambulation. In 2016, this festival was attended by tens of thousands of people. ${ }^{61}$ Since 2007, a large "cultural temple festival of Jade Spring district” (Yuquanqu wenhua miaohui 玉泉區文化廟會) has been organized during the first month on the great square in front of the Yeke juu and Tongshun

\footnotetext{
${ }^{54}$ Erhimbayar, “Mongolian Buddhist Monasteries,” 188-89. The Mergen juu, west of Baotou 包頭, is the only Inner Mongol monastery where the language of liturgy is Mongolian.

${ }^{55}$ Jin Cheng is the gesgüi (master of discipline, proctor) of the Yeke juu and also the abbot of the Xingyuansi 興 源寺 in Küriye (Siregetü Küriye banner/Kulunqi 庫倫旗, Tongliao municipality). His Buddhist name is 'Jam dbyangs dbang phyug/Mo. Jamyang vangcu $\gamma$, but people generally use his birth name. He is married, has children, and studied in a monastery on Wutaishan (Mount Wutai, Shanxi province).

56 This lama lived barefoot for twenty years. He studied on Wutaishan and was involved in the Falungong 法輪功 movement. He was persecuted and managed to escape. He now has many Han Chinese disciples.

${ }^{57}$ When speaking about reincarnate lamas of Inner Mongolia, Buddhist Mongols of Hohhot cite the Twelfth Ulayan gegen, Blo bzang 'jam dbyangs seng ge/Mo. Lobsang Jamyang Sengge (2004-, enthroned in his Ordos monastery in Ejen qoriya banner, 2010) and the reincarnation of the Duyingqor qutu $\gamma$ tu (born in the early 2000s, he is now educated in Kumbum monastery of Amdo/Qinghai province). On Inner Mongol reincarnations, see Charleux, "The Reconstruction of Buddhist Monasteries," 7-8; and Yang, "Nei Menggu zangchuan fojiao jinkuang zhi tantao," 4.

58 "Huhehaote Dazhaosi yinglai lüyou gaofengri jiedaiyouke jin 600 ren." I was told that the largest portion of the entrance fees is kept by the monastery.

59 "Fahui-Nei Menggu Huhehaote Dazhaosi longzhong juban 'song baling' fahui;" "Huhehaoteshi Dazhaosi huanqing randengri;" and "Huhehaoteshi Dazhaosi juban randengjie fahui." Yeke juu organized only two festivals a year (including a cam for the New Year) in the 1990s.

${ }^{60}$ The monasteries are free to decide the frequency and dates of their festivals, but they have to report them to the authorities.

61 "Huhehaoteshi Dazhaosi mani fahui yuanman jieshu."
} 
Isabelle Charleux. Authors' own file, not the published version in Sino-Tibetan Buddhism across the Ages, Ester Bianchi \& Shen Weirong (dir.), Brill : Leyde \& Boston (Studies on East Asian Religious, vol. 5), 2021

street 通順街. It features “exhibitions of popular traditions and popular performances” to attract devotees and tourists of all ethnicities. Commerce, ethnic tourism, and religion are thus intertwined in these festivals.

Between 1999 and 2006, the size of the Yeke juu nearly doubled: the total built area is approximately its imperial-time extension (fig. 5). ${ }^{62}$ The various shrines are oriented toward the south. ${ }^{63}$ The older buildings are located in the central and south-western section. Prior to the local government's investment of more than RMB 10 million in 2006, RMB 20 million were spent to build new temples in the eastern precinct. This was made possible due to donations, mostly by Chinese private donors, private companies, and associations from Inner Mongolia, Beijing, Taiwan, and Hong Kong. ${ }^{64}$ In 2006, eight stūpas were completed in front of the entrance of the western precinct. The old western temple dedicated to the protector deity Pe har (Nayicung süme) in the western precinct was restored and a nine-bay hall (jiujianlou 九間樓)— a two-storied building with nine bays in façade — was built north of it.

Six new temples were built in the new eastern precinct. They are entirely new constructions; with the exception of a Bodhisattva hall, no such halls existed in this area previously (fig. 5). ${ }^{65}$ They are, from south to north:

- an entrance gate;

- a Bodhisattva hall (Pusadian 菩薩殿, Bodisadua-yin duyang). The statue of the Thousand-armed Avalokiteśvara of the Bodhisattva hall is surrounded by twentyone smaller statues of Tārā, offered by private donors (individuals or families) whose Chinese names are inscribed on their pedestal;

- a Jade Buddha hall (Yufodian 玉佛殿, Qas burqantu duүang, 2006-2007, 19x21.6 meters large and 12.88 meters high). It enshrines a 4.4 meter-high Burmese-style statue of Śākyamuni made in Lijiang 麗江 (Yunnan province) and donated in 2006 by Han and Mongol devotees (fig. 6). The statue is made of twenty tons of jade from a whole block; its robe is inlaid with a mosaic of 25,550 rubies and sapphires. ${ }^{66}$

- a Maitreya hall (Daledian 大樂殿). It enshrines a monumental Maitreya statue, giant mandalas, and depictions of the Shambhala kingdom and its kings.

- Paralleling the Maitreya hall in the western courtyard, a Sitātapatrā hall houses a giant statue of Sitātapatrā. The lintel of its main door imitates the decorations found on the main door of the Lhasa Jo khang with sculptures of lions' faces. There was no image of Sitātapatrā in the Yeke juu before.

\footnotetext{
62 "Hushi zongtouzi 3000 yu wan yuan kuojian Dazhao Guanyinmiao." The Yeke juu formerly covered a total area of 29,171 square meters with a built area of 4,145 square meters.

${ }^{63}$ More precisely, toward the south south-east.

${ }^{64}$ The main sponsor of the Jade Buddha hall and the Bodhisattva hall was the Hohhot Xiyuan Construction Company 呼和浩特西苑建築有限責任公司 (“Huhehaote zhongduo guji daguimo xiushan yingjie xiaji lüyou re;” "Huhehaote guji daguimo xiushan yingjie xiaji lüyou re").

${ }^{65}$ In the early twentieth century, the eastern precinct, called Yeke sang ("great treasury") included the main treasury, a small Bodhisattva hall, a five-bay pavilion (Wujianlou 五間樓) used as a kitchen with two big cauldrons for the assemblies' tea, monks' residences, and, in the north-east, the Office of the seals, which administrated all the monasteries of Hohhot (Charleux, Temples et monastères de Mongolie-Intérieure, CD-rom "Yeke juu").

${ }^{66}$ The main sponsors of the statue were Wei Xiangchun 魏相春, general manager of the Beijing Rich Angel Company (北京富貴天使珠寶有限公司), and Chairman Huang Menghua 黃蒙華 of the Inner Mongolia Liyuan Real Estate Group (内蒙古立元房地產集團有限公司) (“Hushi yuji mingnian shang bannian jiangzai Dazhao jiancheng Yufodian").
} 
Isabelle Charleux. Authors' own file, not the published version in Sino-Tibetan Buddhism across the Ages, Ester Bianchi \& Shen Weirong (dir.), Brill : Leyde \& Boston (Studies on East Asian Religious, vol. 5), 2021

- West of the Sitātapatrā hall is the new abbot's residence (fig. 7). Other buildings include a kitchen, a classroom, a guest department, administration building, and monks' lodging.

The eastern courtyard has statues of an elephant, a bull, and a lion; a representation of Sumeru (modelled on the one at Yonghegong), footprints of the Buddha on a stele, and a copy of the nine wells of the Jade Spring. ${ }^{67}$ Huge statues of lions guard the entrance hall. Each construction is marked by a Chinese stele (or an inscription for statues and incense-burners) mentioning the Chinese names of donors, associations, and private firms. As noted above, it is not always possible to distinguish between Han donors and Tümed and other Mongol donors who use a Chinese name. ${ }^{68}$

\footnotetext{
${ }^{67}$ Just south of the Altan Khan square is the Jade Spring (Yuquan 玉泉, or Imperial spring) composed of eight wells said to have appeared under the hoofs of Emperor Kangxi's horse in 1696. The spring was the object of a popular cult and a temple was once dedicated to it.

${ }^{68}$ During the Cultural Revolution, many Mongols stopped using Mongol names. Mongol parents who were trying to protect their children often resorted to giving their children Chinese names to use at school.
} 
Isabelle Charleux. Authors' own file, not the published version in Sino-Tibetan Buddhism across the Ages, Ester Bianchi \& Shen Weirong (dir.), Brill : Leyde \& Boston (Studies on East Asian Religious, vol. 5), 2021

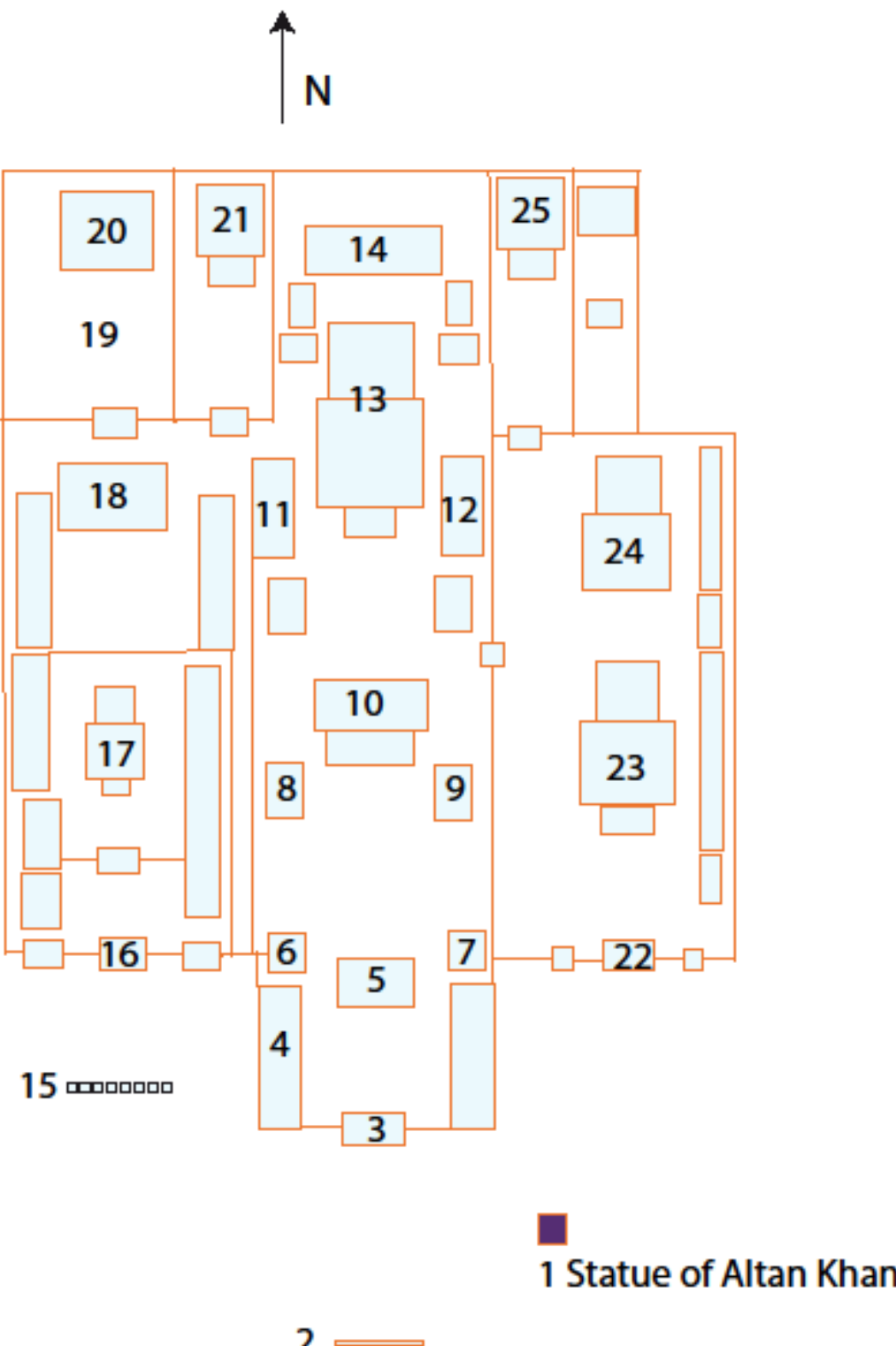

2

Fig. 5. Floorplan of the Yeke juu. 1. Statue of Altan Khan; 2. Triumphal arch;

Central part (old part): 3. Main entrance gate; 4. Shops; 5. Lokapāla hall; 6. Drum tower; 7. Bell tower; 8. Amitābha hall; 9. Amitāyus hall; 10. Puti guodian 菩提过店 (Yama hall); 11. Guhyasamāja hall; 12. Samvara hall; 13. Central temple (Yool copcin: assembly hall and back shrine with the Jo bo statue); 14. Nine-bay hall

Western precinct: 15. Eight stüpas; 16. Entrance hall; 17. Pe har temple (Nayicung süme); 18. Nine-bay hall; 19. Garden; 20. Abbot's residence; 21. Sitātapatrā hall

(Newly built) eastern precinct: 22. Entrance hall; 23. Bodhisattva hall; 24. Jade Buddha hall; 25. Maitreya hall (Tușita hall) 
Isabelle Charleux. Authors' own file, not the published version in Sino-Tibetan Buddhism across the Ages, Ester Bianchi \& Shen Weirong (dir.), Brill : Leyde \& Boston (Studies on East Asian Religious, vol. 5), 2021

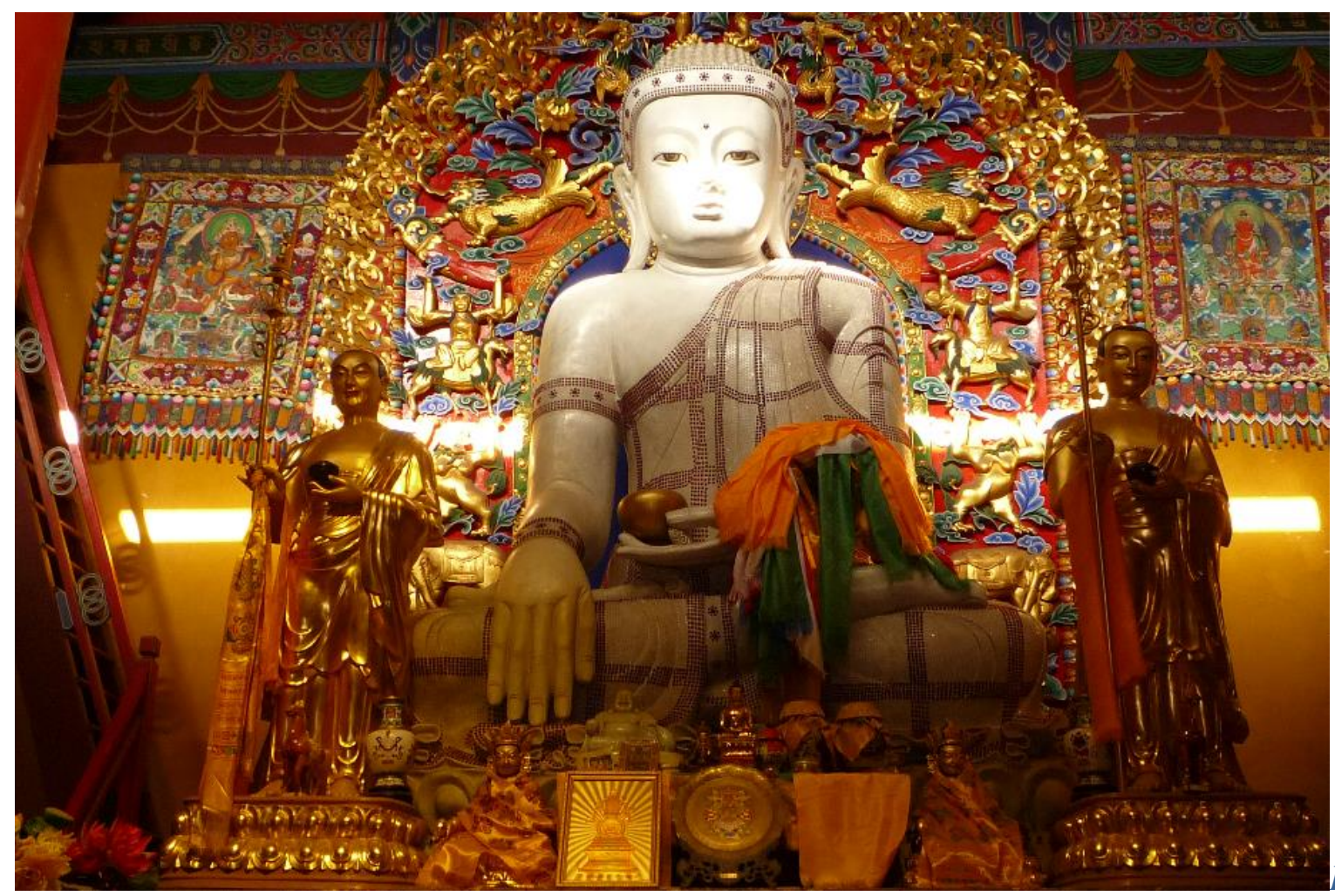

6. Jade Buddha, Yufodian, Yeke juu. (C) M.-D. Even, 2014

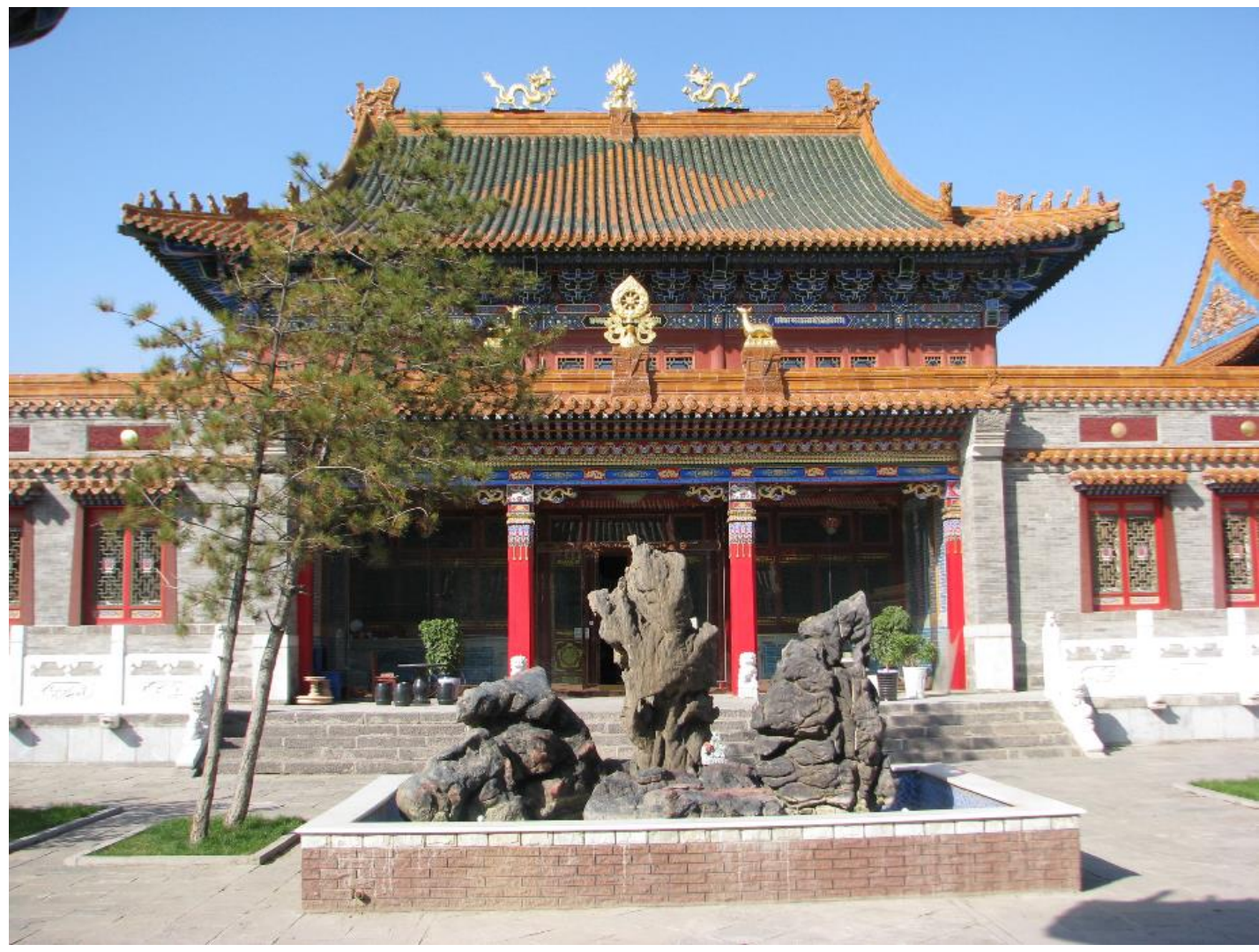

Fig. 7. Abbot's courtyard, Yeke juu. (C) Isabelle Charleux, 2012 
Isabelle Charleux. Authors' own file, not the published version in Sino-Tibetan Buddhism across the Ages, Ester Bianchi \& Shen Weirong (dir.), Brill : Leyde \& Boston (Studies on East Asian Religious, vol. 5), 2021

Table 2. Ritual calendars of Yeke juu and Guanyinsi in the mid-2000s

\begin{tabular}{|c|c|c|}
\hline Lunar months & Yeke juu (Dazhaosi) & Guanyinsi (festivals last 3 days each) \\
\hline \multirow[t]{2}{*}{$\mathrm{I}^{\mathrm{st}}$ month } & 8-15/I: great $t s a m$ & 1/I: Maitreya's birthday \\
\hline & $\begin{array}{l}\text { 15/I: Maitreya festival and } \\
\text { circumambulation }\end{array}$ & 15/I: Lantern festival \\
\hline $\mathrm{II}^{\text {nd }}$ month & & 19/II: Guanyin's birthday \\
\hline \multicolumn{3}{|l|}{ IIII $^{\text {rd }}$ month } \\
\hline $\mathrm{IV}^{\text {th }}$ month & 8-15/IV Kanjur recitation & $\begin{array}{l}\text { 4/IV: Mañjuśrī’s birthday } \\
\text { 8/IV: Śākyamuni’s birthday } \\
\text { 28/IV: Bhaișajyaguru’s birthday }\end{array}$ \\
\hline $\mathrm{V}^{\text {th }}$ month & 13/V: oboya worship & \\
\hline $\mathrm{VI}^{\text {th }}$ month & $\begin{array}{l}\text { 8-15/VI: great festival, cam, and } \\
\text { circumambulation on the } 15^{\text {th }}\end{array}$ & 19/VI: enlightenment of Guanyin \\
\hline \multicolumn{3}{|l|}{ VII $^{\text {th }}$ month } \\
\hline VIII ${ }^{\text {th }}$ month & 14-20/VIII: seven-day mani great ritual & \\
\hline IX ${ }^{\text {th }}$ month & & 19/IX: Guanyin explains the Dharma \\
\hline $\mathrm{X}^{\mathrm{th}}$ month & 22-25/X birthday of Tsongkhapa & \\
\hline $\mathrm{XI}^{\text {th }}$ month & & 17/XI: Amitābha's birthday \\
\hline $\mathrm{XII}^{\text {th }}$ month & $\begin{array}{l}\text { 23-25/XII lamp festival commemorating } \\
\text { Tsongkhapa's death }\end{array}$ & 8/XII: Śākyamuni explains the Dharma \\
\hline
\end{tabular}

Sources: interviews with monks and http://www.nmg.xinhuanet.com/nmgwq/2008-10/21/content_14698854.htm, accessed February 2, 2016.

The Siregetü juu, on the other hand, was not enlarged. In contrast to the Yeke juu, its back courtyard was reconfigured to incorporate a new, gigantic 8x8-bay temple that enshrines a statue of Jo bo Śākyamuni modeled on the Jo khang's Jo bo of Lhasa and a nine-bay hall. The statue was not modeled after the sixteenth century Silver Jo bo/Juu of the nearby Yeke juu, which also follows the Jo khang's Jo bo. ${ }^{69}$ Additionally, the monastery features recently constructed statues of bodhisattvas and dharmapālas. At the time of these renovations, the old monks' houses of the eastern precinct were destroyed.

North-west of the Old City, the Emci-yin juu houses the Inner Mongolia Buddhist School (Nei Menggu zizhiqu fojiao xuexiao 內蒙古自治区佛教学校) and a clinic of Mongol medicine. It is not a monastery anymore. Instead, the old assembly hall was restored ${ }^{70}$ and turned into a Bhaișajyaguru (Medicine Buddha) temple. As of 2016, the school trains about 150 monk-students every year, the youngest being $17-18$ years old. ${ }^{71}$ The Buddhist Association of

${ }^{69}$ Charleux, "The Mongols' Devotion to the Jowo Buddhas."

${ }^{70}$ In the 1990s, the monastery was occupied by a glass factory.

${ }^{71}$ Between 1987 and 1990 the Inner Mongolia Buddhist School was located first in the Badyar coyiling süme (Ch. 
Inner Mongolia is located next to it. There is no other Buddhist school in Inner Mongolia, but about a hundred large monasteries like the Yeke juu and the Badyar coyiling süme have parttime training programs for young monks. ${ }^{72}$ The program at the Yeke juu includes classes that train about ten monks on a three- to five-year curriculum and a course that teaches Mongolian calligraphy. ${ }^{73}$

The Tibeto-Mongol Buddhist monasteries have a Tibetan atmosphere, with ritual scarfs (Mo. qatar, Tib. kha btags), prayer wheels, and wind-horse flags tied to the poles and trees. Some of the new icons are in the "international Buddhist" style: the Burmese-style jade Buddha of the Yeke juu, the footprints of the Buddha, etc. The other main statues strictly follow Tibetan iconography. Nevertheless, the fact that the majority of the donors and tourists at the Mongol monasteries are Han Chinese or sinicized Mongols affects their visual appearance: Chinese visual culture influences, though limited to decorative elements and smaller altar icons, are omnipresent. Signs, name plaques above entrances, boards, and stone inscriptions are written only in Chinese, though rituals are announced in both Chinese and Mongolian. Small icons of Chinese deities (Guanyin, Guandi 關 帝, Caishen, fat Maitreya/Milefo 彌 勒佛, Kșitigarbha/Dizang 地藏), offered by devotees, are placed on altars (fig. 8). The interior decoration (vases, carpets, Chinese-style shanshui 山水 paintings) is entirely Chinese too, and a Chinese garden with strange rocks was built in the courtyard of the Yeke juu's abbot (fig. 7). Chinese dragons chasing a cintāmaṇi (instead of the flaming pearl of the traditional Chinese motif) adorn the roofs of the new temples of the Yeke juu monastery, and Chinese-style carvings, balustrades, and sculptures decorate the new halls and courtyards. The Bhavacakra (Wheel of Life) paintings at the entrances of the central assembly halls of the Yeke juu and Siregetï juu both include a depiction of a judge of hell and his attendants in the Chinese mode (fig. 8). The shops inside the monasteries sell Chinese and Tibetan icons as well as Buddhist books in Chinese only.

Wudangzhao 五當召), the largest of the Inner Mongol monasteries, in Baotou municipality, and then in the Caqar blama juu (Ch. Qingyuansi 慶緣寺), which is located in the Üsütü juu (Ch. Wusutuzhao 鳥素圖召), about 12 kilometers north-west of Hohhot. On the former school and its three-year training program, see Charleux, "The Reconstruction of Buddhist Monasteries," 6; and Yang, "Nei Menggu zangchuan fojiao jinkuang zhi tantao," 56.

72 Tang, "Mengguzu diqu fojiao fazhan de tedian," 375.

${ }^{73}$ On monks' training in the Yeke juu, see Erhimbayar, "Mongolian Buddhist Monasteries," 191. 

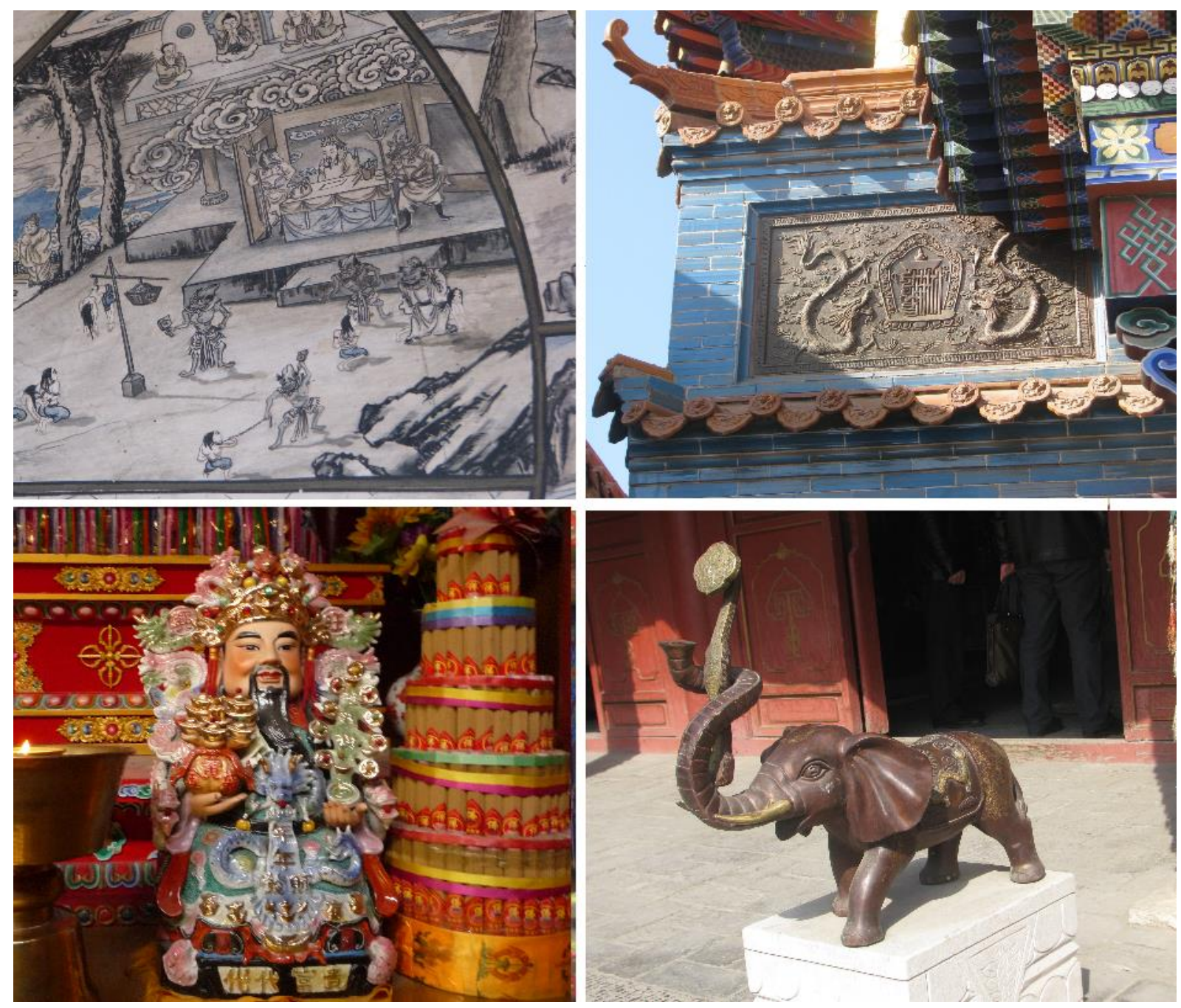

Fig. 8. Chinese decoration within Mongol Buddhist monasteries: Wheel of life (Bhavacakra), central assembly hall of the Yeke juu (top left); dragons surrounding the Kālacakra symbol, Sitātapatrā hall of the Yeke juu (top right); Caishen, Chinese god of Wealth, great assembly hall of the Emci-yin juu (bottom left); Statue of an elephant holding a ruyi 如意 sceptre in front of the Amitāyus hall, Yeke juu. (C) Isabelle Charleux, 2016

\section{The Chinese Buddhist Monastery: the Guanyinsi (Avalokiteśvara Monastery)}

The Guanyinsi, popularly known as Guanyinmiao 觀音廟, located south of the Yeke juu in the Old City, is said to be "the first of the thirteen Chinese temples and monasteries" of Hohhot in the early twentieth century. According to a stone inscription located within the monastery, it was built in the early Jiaqing era (1796-1820), in 1796 or 1799, and rebuilt in 1845. Partially destroyed during the Cultural Revolution, it was rebuilt between 1987 and 1989 by the Hohhot government: its scale was then eight times smaller than it had been in pre-revolutionary times. Its entrance unusually faces north, and it is comprised of three small temples in a single courtyard: a five bay-wide Avalokiteśvara hall (main hall) and two lateral halls - a Kșitigarbha hall (Dizangdian 地藏王殿) and a Mañjuśrī hall (Wenshudian 文殊殿). Other buildings include an entrance gate, an image of Maitreya in a small pavilion that stands in the middle of the 
Isabelle Charleux. Authors' own file, not the published version in Sino-Tibetan Buddhism across the Ages, Ester Bianchi \& Shen Weirong (dir.), Brill : Leyde \& Boston (Studies on East Asian Religious, vol. 5), 2021

courtyard, a meditation room (chanfang 禪房), and six stone inscriptions. The drum and bell towers were not rebuilt. The Avalokiteśvara hall has statues of Guanyin in the center, flanked by his disciples Sudhana (Shancai 善財童子) and Longnü 龍女, and of Mañjuśrī and Samantabhadra on either side. The western and eastern walls have paintings of the different forms of Guanyin. ${ }^{74}$

As mentioned above, from 2005 to 2012, the Hohhot municipality spent more than RMB 20 million on the project to enlarge the Guanyinsi. This was due to the fact that the old monastery was too small to house crowds of believers that could reach up to 60,000 or 70,000 a day, and the lack of space had been judged dangerous in case of crowd movement. ${ }^{75}$ RMB 20,000 from private donations had previously been spent to restore the monastery. ${ }^{76}$ The newly constructed area of the monastery, located east of the old Guanyinsi, opens southward (fig. 9). Its three gigantic halls tower above the nearby six-storied buildings. New buildings included massive temples that feature references to the Forbidden City, such as large marble stones with fiveclawed dragons decorating the staircases of the colossal Avalokiteśvara hall and yellow tiled roofs. It is now the largest monastery in Hohhot: the new buildings are from south to north,

- the entrance hall;

- the lokapāla hall 天王殿 (with statues of the four lokapālas, as well as of Maitreya and Skanda/Weituo 韋䭾菩薩);

- the drum tower (east), the first level of which serves as a qielan hall 伽藍殿 (housing the sixteen qielan guardian deities);

- the bell tower (west), the first level of which serves as an ancestors' hall, zushidian 祖師殿;

- the Avalokiteśvara hall (Guanyindian, also called Yuantong baodian 圓通寶殿, completed and consecrated in 2008) is 35.55 meters high and enshrines a monumental statue of the Thousand-armed thousand-eyed Avalokiteśvara (fig. 10). It rests on a 1.6 meter-high marble platform accessible by a staircase decorated with dragons, while the interior of the hall is decorated with Tibetan-style prayer wheels.

- the Main Buddha hall (hall of the Great Hero or Mahāvīra hall, daxiong baodian 大 雄寶殿). Consecrated and opened in 2011, it is 36.45 meters high; it enshrines statues of Amitābha, Śākyamuni, and Bhaișajyaguru, of the eighteen arhats, and of the eighth century Tibetan thaumaturgist Padmasambhava.

- west of the Avalokiteśvara hall, a Protectors' hall (hufadian 護法殿) was built on a Tibetan model to enshrine fierce protector deities. The main figure is a winged deity who looks like Vajrakīla (rDo rje phur pa), ${ }^{77}$ flanked by two equestrian deities who could be bSe'i khrab/Beg tse and Tsi'u dmar po (fig. 11). ${ }^{78}$ Tibetan items such as

\footnotetext{
${ }^{74}$ Legend says that Guanyin appeared to a man suffering from eye disease in a dream and promised to cure him if he became a monk. He took the robe and the religious name of Juzu 具足 from an old monk of Guandimiao (Xichafang 西茶坊) and built the Guanyinsi near the well where Guanyin had appeared to him. His eyes were miraculously cured, and he became the first abbot of the Guanyinsi ("Huhehaote Guanyinsi-Guanyinsi jianjie"). The Guanyinsi had seven generations of abbots.

75 "Hushi zongtouzi 3000 yu wan yuan kuojian Dazhao Guanyinmiao."

76 "Hushi zongtouzi 3000 yu wan yuan kuojian Dazhao Guanyinmiao."

77 This form of Vajrakīla exists in the Jangter (Byang gter), or Northern Treasures, tradition of the Nyingmapas. I thank Kunsang Namgyal-Lama for such a precise description.

${ }^{78}$ Because my three visits coincided with the monks' period of retreat, I had no opportunity to meet with the abbot or interview monks of the Guanyinsi. The lay devotees that I interviewed called these deities "protectors" and did
} 
prayer wheels, the Kâlacakra symbol, and the om syllable are displayed inside. Except for these statues and the Padmasambhava statue in the Main Buddha hall, the statues and murals of the Guanyinsi are entirely Chinese.

Additional buildings within the complex include two lateral halls, a scriptures hall (zangjinglou/ge 藏經樓/閣), a nianfotang 念佛堂 (recitation hall), a zhaitang 齋堂 (abstinence hall), the abbot's residence (fangzhangshi 方丈室), a guest hall (jiedaishi 接待室), and a kitchen.

The Guanyinsi's abbot, Master Chenghuan 澄還法師, does not hold any position within the Buddhist Association. The monastery only has about twenty Han Chinese monks but—as with many monasteries in other Chinese cities - a very active jushi community, some of whom are Mongols. ${ }^{79}$ The jushis keep watch over the halls, help worshipers, attend rituals, and gather in the Protectors' hall to recite Amitābha's name. A few Mongolian names can be identified on the Chinese stone inscriptions recording names of donors.

The Guanyinsi organizes eight to ten large festivals a year that last three days each, and twice a month the jushis gather to pray and recite Amitābha's name (on the $1^{\text {st }}$ and $15^{\text {th }}$ of each lunar month) (Table 1). Most of their festival days are not the same as those of the Mongol monasteries, which enables devotees to attend them all. Many traders come to worship at the main festival, organized for Guanyin's birthday, on the $19^{\text {th }}$ of the second lunar month. In 2004, the monastery organized seven great Buddhist rituals lasting forty-nine days (Fo qi da fahui 佛 七大法會) for the first time in Inner Mongolia. ${ }^{80}$ On Sākyamuni's birthday (on the $8^{\text {th }}$ day of the fourth month), a statue of Sākyamuni is carried in a procession and given a bath. Other rituals, such as the fangsheng 放生 ritual (release of living animals), are performed on special occasions. During rituals and teaching sessions, which include chanting the Amitäbha Sütra, reciting Amitābha's name, lecturing on the teachings, offering praises, performing acts of repentance, and making vows, the abbot preaches and explains the doctrine to about sixty jushis. ${ }^{81}$ The number of the monastery's visitors is estimated at 300,000 annually. The Guanyinsi has a website that advertises its different activities, ${ }^{82}$ and it organizes services usually found in Chinese monasteries, such as putting up tablets that wish longevity for one's relatives and a rebirth in Amitābha's paradise for their dead.

The $15^{\text {th }}$ day of the fourth lunar month to the $15^{\text {th }}$ of the seventh is a retreat period during which the monks practice intensively; they are not allowed to go outside, and the monastery does not admit monks from outside to "register" (guadan 掛單) at that time. The Guanyinsi has no entrance fees and is often closed to tourists. In contrast with the Yeke juu and the Siregetiu juu, its main income does not come from tourism but from the donations of laypeople.

not know their names. Additional fieldwork will be necessary to understand why and by whom Tibetan and Tibetan-style deities were introduced into this Chinese Buddhist monastery.

${ }^{79} \mathrm{It}$ is not possible to ask questions about the number of jushis in a monastery.

80 佛七 is a seven-day ritual-cum-retreat cycle; at Guanyinsi there are seven cycles that combine different programs: Fo qi 佛七, dabei qi 大悲七, Dizang qi 地藏七, Jingang qi 金剛七, sanshi xinian fahui 三時繫念法會, fahua fahui 法華法會, and fangsheng fahui 放生法會 (“Guanyinsi Huhehaote;" “Huhehaote Guanyinsi-Guanyinsi jianjie").

${ }^{81}$ For instance: "Fahui-Huhehaote Guanyinsi juban sanshi xinian fahui (tu);" and "Jiangzuo-Huhehaote Guanyinsi Chenghuan fashi wei sizhong dizi xuanjiang faben."

82 "Nei Menggu Hushi Guanyinsi kaitong," which is located at http://guanyinsi.fjnet.com/. The address did not work in 2016-2017. 
Isabelle Charleux. Authors' own file, not the published version in Sino-Tibetan Buddhism across the Ages, Ester Bianchi \& Shen Weirong (dir.), Brill : Leyde \& Boston (Studies on East Asian Religious, vol. 5), 2021

The Guanyinsi has a branch monastery (xiayuan 下院) in the countryside about twelve kilometers north-west of Hohhot, not far from the Üsütü juu. ${ }^{83}$ The construction of this monastery between 1998 and 2002 was possible thanks to a local relaxation of the Chinese law that allowed local religious leaders to reopen an existing temple or monastery but prohibits them from establishing a new one.

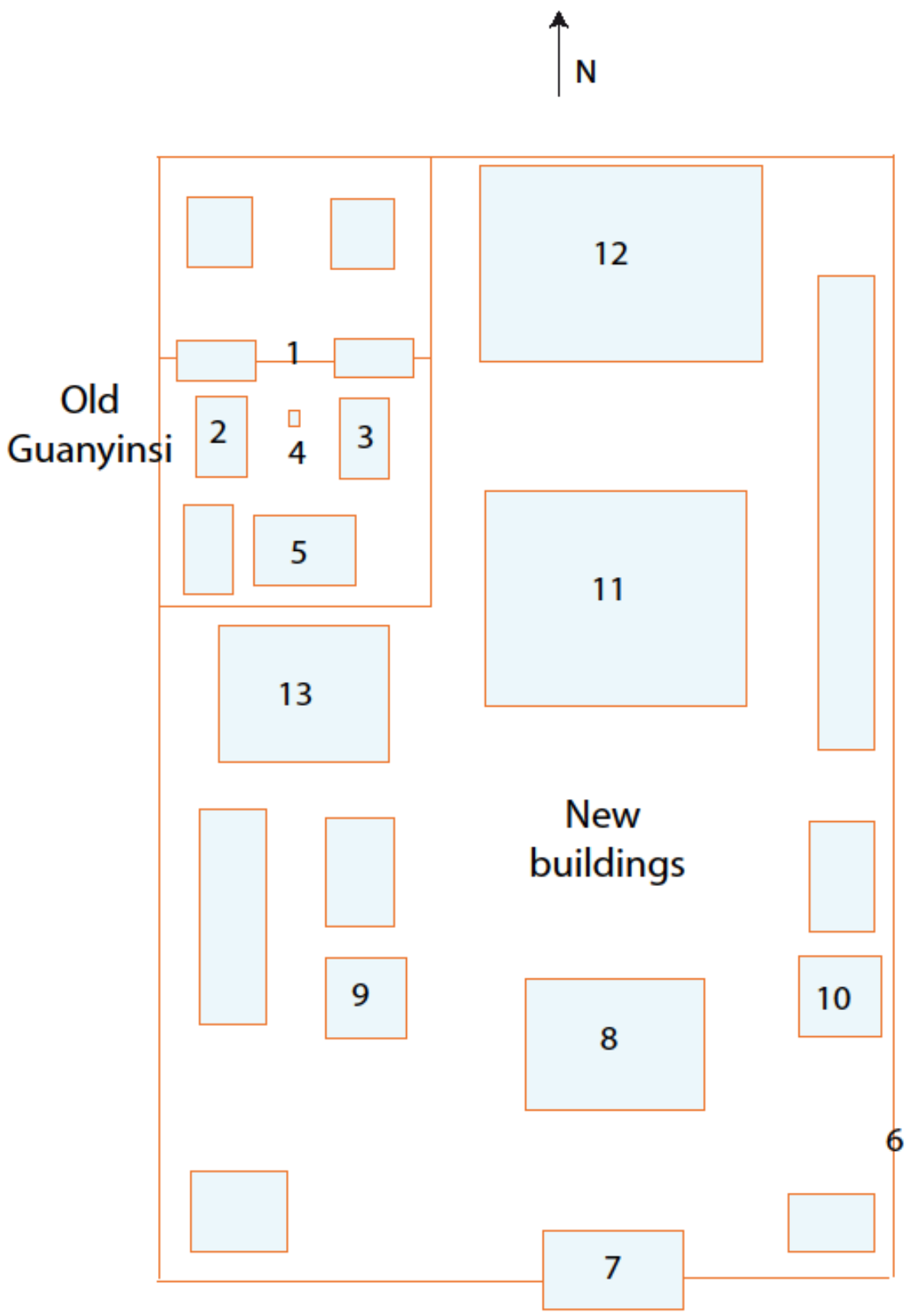

Fig. 9. Floorplan of the Guanyinsi

${ }^{83}$ It opens to the east and covers an area of 15,000 square meters, with a screen wall (zhaobi 照壁), entrance hall, lokapāla hall, Guanyin hall, zushi hall 祖師殿, qielan hall, Kșitigarbha hall (Dizangdian 地藏殿), nianfotang 念 佛堂, zangjing ge 藏經閣, baoentang 報恩堂, scriptures hall, pagoda, kitchen, and zhaitang ("Huhehaote Guanyinsi-Guanyinsi jianjie"). 
Isabelle Charleux. Authors' own file, not the published version in Sino-Tibetan Buddhism across the Ages, Ester Bianchi \& Shen Weirong (dir.), Brill : Leyde \& Boston (Studies on East Asian Religious, vol. 5), 2021

Old temple: 1. Entrance; 2. Mañjuśrī hall; 3. Kșitigarbha hall; 4. Maitreya; 5. Avalokiteśvara hall

New temples: 6. Present-day entrance; 7. Entrance hall; 8. Lokapāla hall; 9. Drum tower/Qielan hall; 10. Bell tower/ancestors' hall; 11. Avalokiteśvara hall (Yuantong baodian); 12. Main Buddha hall; 13. Protectors' hall

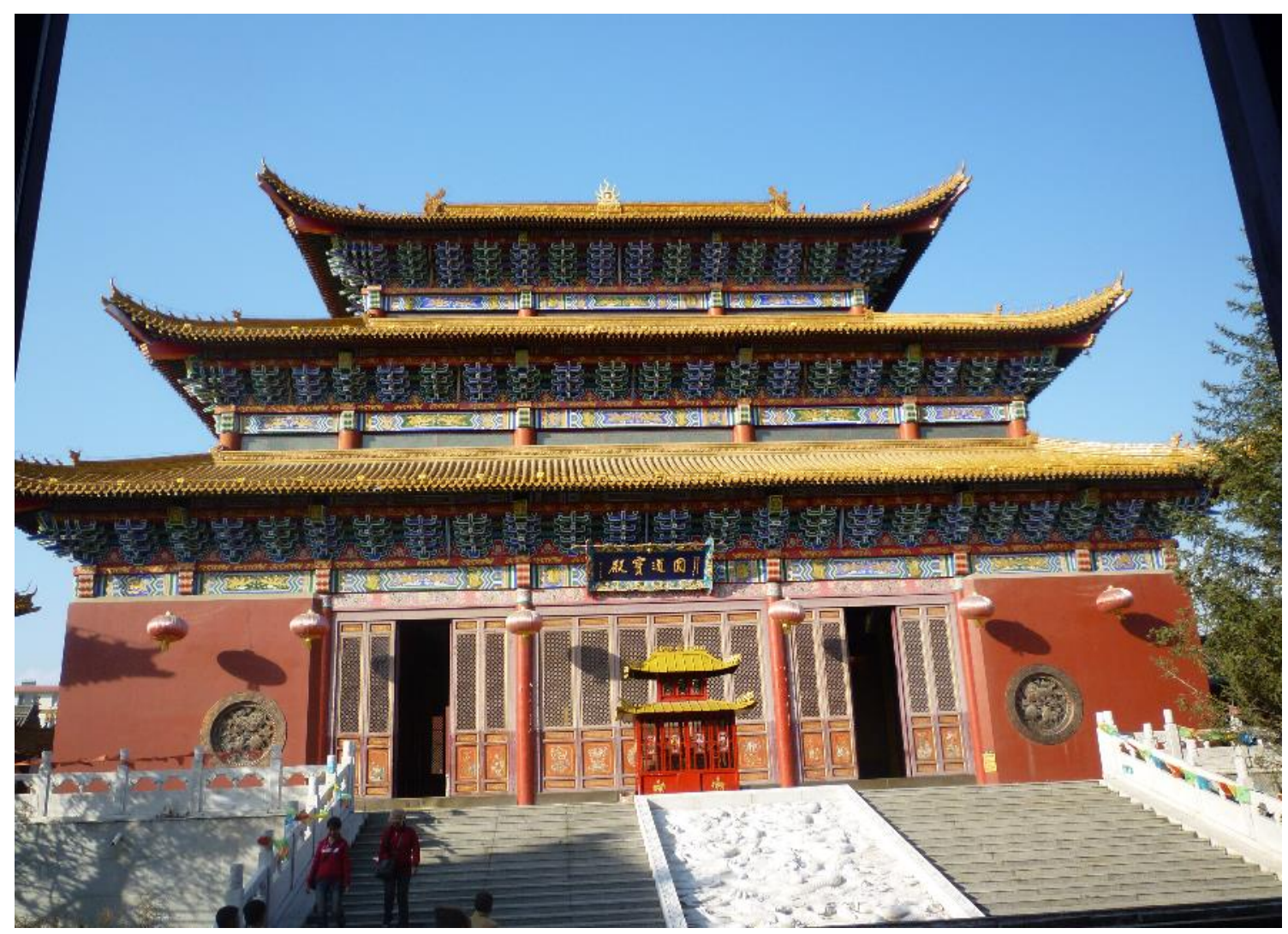

Fig. 10. Avalokiteśvara hall, Guanyinsi. (C) Isabelle Charleux, 2016 


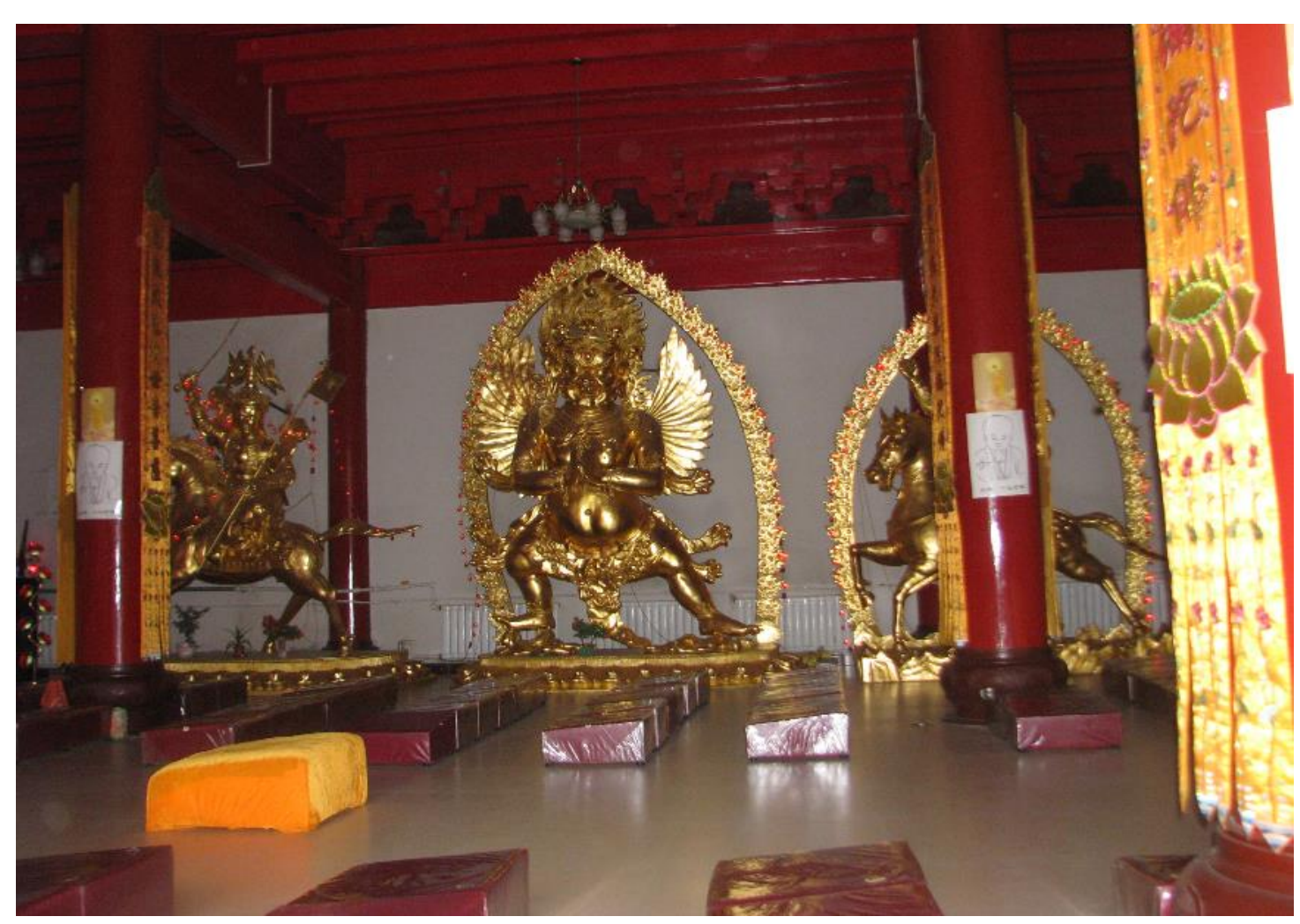

Fig. 11. Protector deity, Protectors' hall of the Guanyinsi. (C) Isabelle Charleux, 2016

\section{The Burqan Stūpa}

The Burqan stūpa (Ch. Baoerhan fota 寶爾汗佛塔, Mo. Burqan suburya, lit. Buddha stūpa) was built between 2006 and 2008 south of the city in Yuquan park and is affiliated with the Guanyinsi. ${ }^{84}$ The new buildings of the Guanyinsi now open toward the south, facing the park and the stūpa and thus creating a new and coherent Buddhist space. The project was developed by the Yuquan district Government, but the stüpa was entirely financed by private donations and cost more than RMB 22 million. A reincarnation from Eastern Tibet, the $21^{\text {st }}$ Longduo Danzeng Rongbo 龍多.丹增榮波活佛 (1954-), Vice president of Larung Gar (bLa rung sgar) Five Sciences Buddhist Academy in Sertar, Sichuan 四川色達喇榮五明佛學院副院長, ${ }^{85}$ selected the place, decided the design, fixed the rules for its construction, and selected "eminent

\footnotetext{
${ }^{84}$ On an old map of Hohhot that is displayed in the Tabun suburyan-u süme museum, just south of the Guanyinsi (hence, outside of the city wall) was the Dongyuemiao 東岳廟, Temple of the Eastern Peak.

${ }^{85}$ According to Nicola Schneider (2013: 381), this Nyingmapa master is known in Tibetan as Lungtog Gyatso (Lung rtogs rgya mtsho, ca. 1954-); he was recognized as the embodiment of the Shugchung Tülku (Shugs chung sprul sku) of Do Shugchung Monastery (rDo shugs chung dgon) in Golog. After taking the position of Vice President of the Buddhist Academy, he was designated by Jikmé Püntsok ('Jigs med phun tshogs) as his successor. He has conferred ordinations on the nuns of Tashi Gönsar on several occasions. According to a Chinese source, he would be the reincarnation of a disciple of Padmasambhava ("Longduo Danzengrongbo huofo lishi yinghua jianjie"). I could not entirely reconstruct his Tibetan name: Lungtog Tenzin Rongbo (Tib. Lung-rtogs bstan 'dzin rong bo?). On the influence of the Larung gar (Ch. Wuming foxueyuan 五明佛學院) among Chinese lay Buddhists in China proper, see Alison Denton Jones' contribution (Chapter Nine).
} 
Isabelle Charleux. Authors' own file, not the published version in Sino-Tibetan Buddhism across the Ages, Ester Bianchi \& Shen Weirong (dir.), Brill : Leyde \& Boston (Studies on East Asian Religious, vol. 5), 2021

monks" (gaoseng 高僧—which does not specify whether they were lamas or Chinese Buddhists) to help with the construction work. He directed the consecration ritual that took place on 14 February $2008 .^{86}$

The stüpa's height is 81.60 meters. On the instructions of Longduo Danzeng Rongbo, its nine stories were filled with an impressive number of statues (about two thousand), relics, texts, and other consecration objects belonging to both the Tibetan and Chinese traditions (Table 3; fig. 12). The precious scriptures belong to both the Tibetan and Chinese corpuses and statues have either Chinese or Tibetan iconographies. According to Longduo Danzeng Rongbo,

Worshipping this stūpa brings the same merit as worshiping the sacred places of Wutaishan or Putuoshan. If we add together the totality of the treasures of the monasteries of Wutaishan, their blessings are the same as those [brought by the worship of] the Burqan stūpa.

This stūpa liberates through seeing, touching, circumambulating, and praying. Circumambulating the stūpa brings the same merit as building it. ${ }^{87}$

According to Longduo Danzeng Rongbo, when circumambulating the stūpa, one has to recite sütras and make the vow that all the "mother-sentient beings" 88 will become buddha. Thanks to this stūpa, Hohhot will have no more large fires, floods, or earthquakes. The Burqan stūpa will become known in the whole world: "This pagoda will enhance the prosperity of the country and the peace of the world. It is of great significance to the prosperity of Buddhism in Inner Mongolia, China, and the rest of the world." $\$ 89$

He also explained that the presence of the sacred texts inside makes the circumambulation of the stüpa equivalent to the recitation of the sacred texts (like the turning of the praying wheels): "If great monks recite the Tripitaka, it takes several years, but this practice is now accessible to ordinary laypersons." 90 as the stüpa is the dharmakāya of the Buddha, one must turn in the correct way. The Chinese now practice circumambulation, a practice previously reserved to Tibetans and Mongols. Thus, a sign in Chinese indicates the correct direction for circumambulation. The Mongols say that the Han Chinese have a tendency of turning counter-

\footnotetext{
86 "Baoerhan fota."

87 "Baoerhan fota." All translations are mine. In another version of his speech, he said: "This stūpa will enhance the prosperity of the country and the peace of the world. It is of great significance to the prosperity of the Dharma and the liberation of sentient beings in Inner Mongolia, China, and the rest of the world. The treasures enshrined in this stūpa are extremely numerous, and circumambulating this particular stūpa produces the same merit as making a pilgrimage to the two hundred monasteries of Wutaishan or to Lhasa. Once you have done this, it is unnecessary to go and worship [in] any other places; now that there is this stüpa, it suffices completely. Those who only see this stüpa will eventually be reborn in Maitreya's Pure Land and be liberated; those who directly encounter this kind of treasure will not miss any opportunity for ten million (years) and will certainly bring forth the bodhicitta in front of the stüpa, make the vow of attaining Buddhahood during this life, recite sincerely the Hundred-syllable [mantra of Vajrasattva] and the mantra of interdependent origination. You just need to have some spare time and correctly make circumambulations of the stūpa until your feet are really painful; you can also kowtow in front of the stūpa. If you all attach importance to this stüpa, then this stüpa will be known worldwide..." ("Shijie diyi fota: Baoerhan fota").

${ }^{88}$ Lit. "all the sentient beings who have been mothers," meaning that any sentient being may have been our mother in a previous life.

89 "Shijie diyi fota: Baoerhan fota."

90 "Baoerhan fota."
} 
clockwise in order to directly reach the Buddha. ${ }^{91}$ Han Chinese and Mongols perform periodical rituals at the stüpa. For instance, on January 11, 2009, to commemorate the anniversary of the death of Jikmé Püntsok (1933-2004), ${ }^{92}$ lay Buddhists from Hohhot and Ordos made a large offering of lamps on an altar north of Burqan stūpa, and the jushis recited the "Light Offering Prayer" by Atiśa to make the vow of saving all sentient beings. ${ }^{93}$ On January 28, 2010, the monks of the Guanyinsi made a ritual offering of a million lamps to Kṣitigarbha to pray for world peace. $^{94}$

Around the stüpa are Tibetan and Chinese-style icons (notably Kṣitigarbha), Tibetan prayerflags, and also prayer-flags written in Chinese, with the Foding zunsheng tuolonijing 佛頂尊 勝陀羅尼經 (Uṣnīṣa vijaya dhāraṇī sūtra), etc. The Burqan stūpa is therefore Tibetan in shape and Sino-Tibetan in content; it is dedicated to the devotion of laypeople, and laypeople can obtain the same merit as monks since circumambulation is said to be equivalent to reading the whole Tripitaka.

The great Burqan stūpa, which has become a major landmark in the city, has achieved its goal; it is a shared ritual place that monks and devotees belonging to both traditions of Buddhism circumambulate. The Hohhotians have appropriated the square north of it, which has become a main place of gathering (playground, dance, fun fair, markets, and so on).

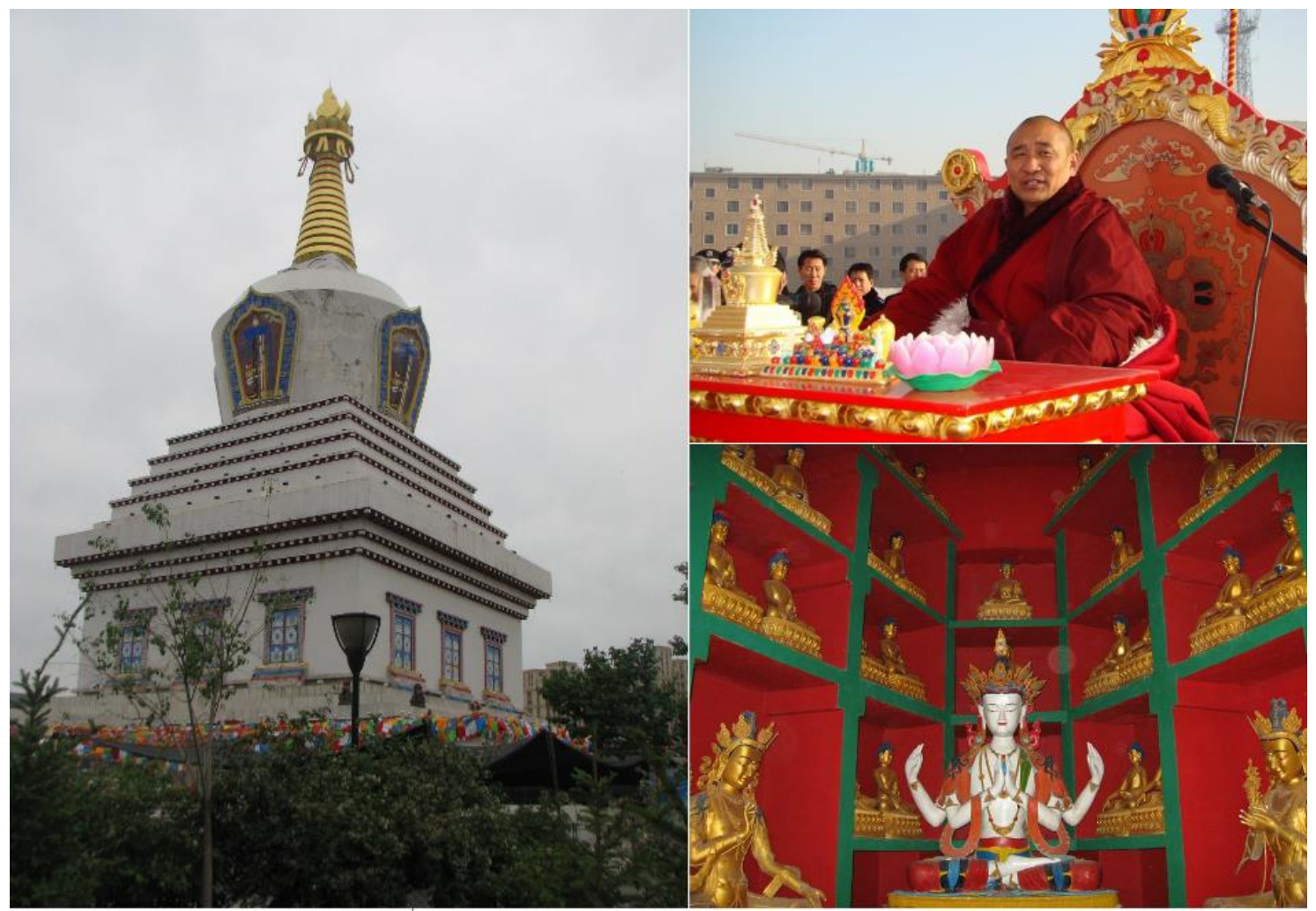

Fig. 12. Burqan stūpa, exterior (C) Isabelle Charleux, 2016); interior and consecration ritual (website "Baoerhan fota")

\footnotetext{
${ }^{91}$ Uranchimeg, oral communication, 2016.

92 The great Nyingmapa master who established the Larung Buddhist Institute.

93 "Baoerhan ta qian gongdeng jinian fawang."

94 "Fahui-Huhehaote Guanyinsi juban 'Puxian yungong' baiwan gongdeng fahui."
} 
Isabelle Charleux. Authors' own file, not the published version in Sino-Tibetan Buddhism across the Ages, Ester Bianchi \& Shen Weirong (dir.), Brill : Leyde \& Boston (Studies on East Asian Religious, vol. 5), 2021

Table 3: Interior filling of the $\mathbf{8 1 . 6 0}$ metres Burqan stūpa

\begin{tabular}{|c|c|}
\hline $9^{\text {th }}$ floor & Precious stones such as crystal, dharmacakra \\
\hline $8^{\text {th }}$ floor & $\begin{array}{l}\text { one-thousand precious vases symbolizing peace, prosperity, wealth, and } \\
\text { destruction of calamities }\end{array}$ \\
\hline $7^{\text {th }}$ floor & $\begin{array}{l}700,000 \text { tsha tshas made by a thousand jushis from the whole of China, starting } \\
\text { with Hohhot under the guidance of Longduo huofo. Every day about three- } \\
\text { hundread jushis made tsha tshas; good earth was chosen and transported by truck } \\
\text { from the Daqing Mountains to a brick factory in Tümed Left banner. The jushis } \\
\text { slept in the factory and did all the kneading, mixing, printing, and firing with their } \\
\text { own hands. The tsha tshas were sun-dried, packed, and shipped to Hohhot to be } \\
\text { placed in a special urn. The whole process took three months }\end{array}$ \\
\hline $6^{\text {th }}$ floor & $\begin{array}{l}\text { Buddhist scriptures occupy three stories, including the Kanjur (1,100 parts), the } \\
\text { Bhaisajyaguru sūtra (10,000 vol.), the Mahāmudra (大手印, 2,000 vol.); the } \\
\text { Kșitigarbha sütra (3,000 vol.), the Great Perfection (大圆满, } 2000 \text { vol.), the } \\
\text { Mituojing 弥陀经 (2,000 vol.), the Amitābha sūtra (1,000 vol.), and the Qianlong } \\
\text { Tripitaka (13 parts). The sūtras and their editions were chosen by Longduo huofo }\end{array}$ \\
\hline $5^{\text {th }}$ floor & $\begin{array}{l}\text { the eight great bodhisattvas with a large image of Four-armed Avalokiteśvara in } \\
\text { the center }\end{array}$ \\
\hline $4^{\text {th }}$ floor & images of the eight manifestations of Padmasambhava \\
\hline $3^{\text {rd }}$ floor & 2,000 small images of Amitābha, Śākyamuni, and Bhaișajyaguru \\
\hline $2^{\text {nd }}$ floor & $\begin{array}{l}\text { relics of the ten great arhats (Ananda, Upali, Rahula, Sariputra, Sīvalī, } \\
\text { Maudgalyayana, Bakula, Kañkhā Revata, and Mahagaxi 马哈嘎 西 [Mahā } \\
\text { Kāśyapa]?) }\end{array}$ \\
\hline $1^{\text {st }}$ floor & rare relics of Buddha Śākyamuni (brain, bone, and blood) \\
\hline
\end{tabular}

Source: "Baoerhan fota gongfeng zhuangcang shengwu zongti jieshao"

\section{Why does the Tibetan-style Burqan Stūpa Belong to the Guanyinsi?}

Lay donors are responsible for the invitation of the Tibetan master and the subsequent building of the Burqan stūpa; they may be also responsible for the introduction of Tibetan deities into the Guanyinsi. The sponsors of the stūpa did not copy from the Mongol monasteries, but instead introduced Tibetan tradition directly from Tibet, capitalizing on the craze for Tibetan Buddhism that was rampant among the young, educated Han urban middle-class and business elite, and which is investigated by Alison Denton Jones in Chapter Nine. ${ }^{95}$ They did not invite a Mongol

\footnotetext{
${ }^{95}$ On Chinese interest in Tibetan Buddhism, especially in Tantric practices, in the twentieth and twenty-first centuries and attempts at harmonizing Tibetan Buddhism with Chan and Pure Land Buddhism, see Chen, "The Tantric Revival," 394-415. On the origins of the phenomenon, see also Martino Dibeltulo Concu's contribution in Chapter Six. On the movement of tantric revival in Han cities since the 2000s, see Jones, "Contemporary Han Chinese Involvement in Tibetan Buddhism;" Smyer Yü, The Spread of Tibetan Buddhism in China; Terrone, "Messengers from Tibet's Past;" and Bianchi, "A Religion-Oriented 'Tibet Fever." Jones (ibid.: 542) has noted the difficulty that Tibetan masters have with obtaining permission to teach in officially registered monasteries; but in the case of Hohhot, the authorities supported the invitation of the Tibetan master.
} 
Isabelle Charleux. Authors' own file, not the published version in Sino-Tibetan Buddhism across the Ages, Ester Bianchi \& Shen Weirong (dir.), Brill : Leyde \& Boston (Studies on East Asian Religious, vol. 5), 2021

Gelugpa lama but a Nyingmapa lama from Larung Gar. The Mongol monasteries of Hohhot exclusively belong to the Gelugpa school, but for Han Buddhists, Larung Gar "universalist" Buddhism is seen as more "authentic" and "pure" than Mongol Buddhism. ${ }^{96}$ These Chinesespeaking Nyingmapa masters from Larung Gar have, since the late 1980s, deployed proselytizing activities among laypeople in Chinese cities and tried to reconcile Tibetan Buddhism with Chinese practices in the dissemination of their teachings. As Bianchi and Smyer Yü have shown, the Nyingmapa (and above all the rDzog chen) masters have contributed to the popularization of the Tibetan Dharma among laypeople, which corresponds to a new phase in the spread of Tibetan Buddhism in China: they aim at "globalizing Tibetan Buddhism." "The Nyingmapa master invited to Hohhot may have created a new iconography to give a protector to the Guanyinsi. With its attached Tibetan-style stüpa and its Protectors' hall with Tibetanstyle wrathful deities, the Guanyinsi thus proposes to its lay practitioners a more complete and global Buddhism which is Chinese in essence but complemented by fashionable Tibetan traditions - mostly of tantric inspiration. However, there is no full-fledged religious hybridization as observed in the Sino-Tibetan tradition of Nenghai 能海 (1886-1967), and notably practiced on Wutaishan (on which see Ester Bianchi and Wei Wu's contributions in Chapter Seven and Chapter Eight), because the liturgy, rituals, and main icons all follow Chinese Buddhism.

\section{Charity}

There is obviously competition between the Yeke juu and the Guanyinsi in terms of their monumentality and religious activities, but also in terms of their charity and social work; as in other parts of China, monasteries are encouraged by the state to provide charitable services to impoverished local communities. Since 2008, the Guanyinsi, Yeke juu, Siregetii juu, and Emciyin juu have organized charitable activities to support poor students and the elderly and to bring relief to areas that have suffered natural disasters. These are occasions for public speeches with the participation of the city authorities. In eight years, the Yeke juu spent RMB 3 million and helped more than 7,000 households. The Guanyinsi gives donations to poor areas of Hohhot and its schools. To give some examples, in 2007, Hohhot Buddhist monasteries distributed RMB 180,000 for earthquake relief, helping the poor, and other charitable activities. In 2012, the Yeke juu, Siregetï juu, Emci-yin juu, Üsütü juu, and Guanyinsi gathered RMB 24,000 in

\footnotetext{
${ }^{96}$ They criticize Mongol lamas who take wives, but they may not know that Nyingmapa masters are also allowed to marry.

${ }^{97}$ Smyer Yü, The Spread of Tibetan Buddhism in China. Many of these Tibetan masters are fluent in Chinese and go to Chinese cities to give public, or more often private, lectures to devotees. rDzog chen teachings are often proposed as similar to Chan, and Nyingmapa masters present Tibetan Buddhism as perfectly compatible with Confucian culture. "This means that they perceive their form of the Buddhist dharma not as a seal of identity based on exclusion, but rather as a powerful tool capable of 'saving the world' and that they are willing to share with other beings, even — and in many cases especially — with the Han Chinese people" (Bianchi, "Teaching Tibetan Buddhism in Chinese"). These masters promote moral behavior, use modern technologies (notably websites in Chinese) to popularize Tibetan Buddhist teachings among the Chinese, and give empowerments. Bookshops selling books in Chinese on Tibetan Buddhism, meditation, and biographies of the great masters are found everywhere. These masters who are familiar with global market dynamics are often accused of commodifying Tibetan Buddhism. On the influence of Larung Gar in Nanjing, see Jones, "Contemporary Han Chinese Involvement in Tibetan Buddhism," 543, and Chapter Nine in the present volume. For a study of Tibetan Nyingmapa charismatic masters based in Eastern Tibet, see Terrone, "Messengers from Tibet's Past."
} 
Isabelle Charleux. Authors' own file, not the published version in Sino-Tibetan Buddhism across the Ages, Ester Bianchi \& Shen Weirong (dir.), Brill : Leyde \& Boston (Studies on East Asian Religious, vol. 5), 2021

order to provide six scholarships for poor students to study at prestigious Chinese universities. ${ }^{98}$ On January 20, 2016, the Yeke juu, along with the Charity Association (Cishan zonghui 慈善 總會) of Yuquan district and the Inner Mongolia Red Sun food company 內蒙古紅太陽食品 有限公司, organized “Love and Warmth Charitable Donor Activities” (獻愛心送溫暖慈善捐 助活動). The Yeke juu offered nine hundred portions of rice, flour, and oil to the poor of Yuquan district and the Muslim district - a value of RMB 300,000 — while Red Sun offered four hundred portions - a value of RMB 20,000. ${ }^{99}$ Although Buddhist philanthropic endeavors such as providing relief to the victims of natural disasters and helping the poor have expanded all over China in the last few years, they are often not undertaken on the monasteries' own initiative but as a result of political obligation and at the instigation of the local government. ${ }^{100}$

\section{Other Mongol and Chinese Places of Worship}

The other Chinese temples and monasteries in Hohhot are very small. They include the Daoist Taiqinggong in the Xincheng district ${ }^{101}$ and the Caishenmiao south of the Yeke juu. Built in the early Qing period by the traders of Suiyuan and restored several times, ${ }^{102}$ the Caishenmiao housed a "patriotic society" that fought against the Japanese invasion. It was restored in 2008. Nearby is an equestrian statue of Emperor Kangxi (r. 1661-1722), a reference to the legend about Kangxi's horse making the Jade spring gush out. ${ }^{103}$ Another Mongol monastery, the Rabjai-yin juu (Ch. Hongqingsi 弘慶寺) was partially preserved south of the Yeke juu and is currently being restored; its future use is not clear.

In addition to the above-mentioned temples and monasteries, people continue to pray and offer prayer-flags and ritual scarves around trees at a monastery that was turned into a museum: the Tabun suburyan-u süme/Wutasi. The Hohhot government spent more than RMB 8 million to rebuild this monastery south of its peculiar pagoda (a nationally protected cultural heritage object) in 2006. ${ }^{104}$ All of the halls, except one, display newly made Buddha images and mural paintings. The main assembly hall, however, serves as a museum of the history of Hohhot and of this peculiar pagoda. In the main courtyard there is a large incense burner given by donors

\footnotetext{
98 "Huhehaote fojiaojie zizhu 6 ming xinsheng shang daxue."

99 “'Xian aixin song wennuan cishan juanzhu huodong' zai Huhehaoteshi Dazhaisi zhaokai," 2016. According to Shuang ("Chengshi fojiao simiao wenhua de baohu," 47), participation of monasteries to the public welfare, charitable and other social services in Hohhot is not high.

100 Laliberté, "Buddhist Charities."

101 Yishuting South street 藝術廳南街. This monastery was founded in 1739, and Empress Dowager Cixi offered a Ming dynasty Daozang 道藏 and many other gifts to it. Daoist masters from the Baiyunguan 白雲觀 in Beijing used to go there to give teachings. The deities worshipped are Yuanshi tianzun 原始天尊, Lingbao tianzun 靈寶 天尊, Daode tianzun 道德天尊 and the past masters of the monastery ("Nei Menggu Huhehaoteshi Taiqinggong caijing"). The article "Nei Menggu zizhiqu zongjiao gaishu" mentions a second Daoist monastery, Huiyunguan 慧雲觀, but I could not locate it.

${ }^{102}$ Several guilds of the Old City, such as the tailors' guild, the papermakers' guild, and the woolen goods guild, were housed within the grounds of the Caishenmiao (Gaubatz, Beyond the Great Wall, 240).

103 See Charleux, "Kangxi/Engke Amurulang," 8.

${ }^{104}$ Old photographs and archives were used as sources for the rebuilding ("Huhehaoteshi fuyuan Qingdai mingsiCidengsi"). Three central temples and eight lateral temples were rebuilt and dedicated, as they were in the past, to the Five Tatāghata Buddhas ("Huhehaoteshi xiayuan Qingdai mingsi: Cidengsi”). On its history, see Charleux, Temples et monastères de Mongolie-Intérieure, CD-rom: “Tabun suburyan-u süme.”
} 
from Zhejiang province, and miniature "Buddha towers" stand in front of the Vairocana hall. ${ }^{105}$ As is the case elsewhere in China, it is not always immediately clear when entering a monastery whether it is a museum or an active place of worship that sells entrance tickets. Interestingly, the Tabun suburyan-u süme was rebuilt according to the strict rules of Tibetan Buddhism, with consecration formulas in Lantsa script written on the beams. ${ }^{106}$ It is therefore a consecrated temple-museum.

\section{Buddhist Lay Devotees and Tourists}

Based on interviews and lists of donors engraved on steles, it appears that both Chinese and Mongol Buddhist monasteries attract a majority of Han and a minority of Mongol devotees. Although they are still ethnically divided in terms of their clergy (there are no Han Chinese lamas for instance), throughout the year Han and Mongol devotees mix together during rituals and festivals at both types of monasteries. The majority of the Tümed Mongols living in Hohhot are not believers of Tibeto-Mongol Buddhism; some of them are devotees of Chinese Buddhism or of Chinese cults. ${ }^{107}$ An increasing number of Hohhot Mongols is interested in Pure Land Buddhism and enroll as jushis of the Guanyinsi. ${ }^{108}$

For the laity, religion is therefore not an ethnic marker anymore. ${ }^{109}$ However, lay devotees do not come to the Mongol and Chinese Buddhist monasteries for the same reasons. Those who visit the Mongol monasteries predominantly have a "traditional" attitude towards religion, emphasizing devotional practices such as devotions to "objects of worship" (sitügen): burqan (Buddha [images]), scriptures, and reincarnated or especially charismatic lamas. They make prostrations, circumambulations, and prayers, turn prayer-wheels, tell their rosary beads, and burn incense. They make donations - offerings of money to pay for the tea at monks' assemblies, repair or build a temple or a stüpa; offerings of food and small icons on the altars, clothes for statues, pillar decorations, etc.-and ask for specific rituals when needed. They queue to be blessed by charismatic great masters and reincarnations. They are not interested in meditation or teachings.

Mongols living in Hohhot often go to worship the Silver Juu icon of the Yeke juu when their relatives from the countryside visit the city. Old Mongols and Mongols from the countryside behave like fervent devotees; some of them make pilgrimages to the sacred Mount Wutai in Shanxi and to see reincarnated lamas. Urban Mongols and Han Chinese are less demonstrative. Most of them come for festivals only, and the temples are deserted on ordinary days save for a few tourists. This traditional attitude toward religion is usually referred to as "a culture of belief": lay Buddhists have a passive attitude and rely on religious specialists. ${ }^{110}$

The Yeke juu and the Siregetü juu are unwilling to keep up with lay demand for Buddhist

\footnotetext{
105 One gives an offering for removing a cover to reveal a small Buddha image on its surface.

106 The Lantsa consecration formulas were checked by Françoise Wang-Toutain in 2009.

${ }^{107}$ Shuang, "Chengshi fojiao simiao wenhua de baohu," 45.

${ }^{108}$ Uranchimeg, oral communication, 2016.

${ }^{109}$ Referring to Mongol Buddhism in Hohhot, Shuang stresses that "it is a shared religion, a religion of both the Mongols and the Han with no clear ethnic boundaries” (無明顯的族群之邊界) (“Chengshi fojiao simiao wenhua de baohu," 46).

${ }^{110}$ Mair, "Cultures of Belief," 12, and also "Rebirth Control."
} 
practice; the lamas do not preach, teach, or translate the sutras for laypeople. They issue lay Buddhist identification cards, written in Chinese only, on the model of the Chinese Buddhist monasteries, but there is no lay Buddhist community comparable to the Chinese jushis who gather to pray together in the Guanyinsi and wear special garments. Furthermore, the Mongol monasteries are not especially interested in attracting Han followers. ${ }^{111}$ They do not organize rituals for ancestors, hold ghost festivals, or offer space for laypeople to dedicate red and yellow stripes of paper or tablets for their relatives and their dead, as is frequently seen in the assembly halls of Mongol monasteries in Tongliao, for instance, and in the Gelugpa monasteries on Wutaishan. They nevertheless attract many Han Chinese devotees, including Communist Party officials and police officers.

The Guanyinsi attracts both these "passive," "traditional" devotees and laypersons who are looking for a better understanding and practice of Buddhism, in which they see ethical resources and moral direction against materialism. These lay Buddhists engaged in learning about the Dharma and practice form the jushi community of the Guanyinsi. As is the case in other Chinese cities, they are very active; they gather to recite Amitābha's name, read books, attend teachings, and keep an eye on the temples' rooms. As Gareth Fisher has observed of Beijing's Guangjisi, the jushis form a kind of parallel organization ${ }^{112}$ to the Buddhist clergy. Yet at Hohhot's Guanyinsi they seem to have had an important role in the introduction of Nyingmapa Tibetan influences, since it was they who took the initiative to invite a reincarnated master from Larung Gar. The activities of the jushis, who generally belong to the educated urban upper and middleclass, represent a "modern trend" of Chinese Buddhism. This same trend has played a major role in the revitalization of Tibetan Buddhism in China. The Mongol Buddhist monasteries of Hohhot, however, do not seem to be influenced by this modern trend.

The city's urban monasteries benefit from the extraordinary growth of tourism permitted by the recent economic boom and extended vacations. The great majority of tourists are Han Chinese coming from Beijing, the main cities of northern China, and abroad who come to Inner Mongolia to experience the steppe (caoyuan 草原). Tourists also worship in temples: "religious tourists" or "tourist worshippers" burn incense and prostrate themselves in front of the deities, but nevertheless distinguish themselves from worshipers by taking photos and talking loudly.

\section{Conclusion}

Few cities in China, except perhaps Chengdu, have Chinese Buddhist and Tibeto-Mongol Buddhist monasteries on an equal footing. Most scholars who have studied the influence of Tibetan Buddhism in China have focused on the quasi-mono-ethnic cities of inner China and have not looked at the Inner Mongol case.

Since its foundation in the late sixteenth century, Hohhot was a peculiar example of a border city. The absence of ethnic segregation in the Old City and the cohabitation of different religions

\footnotetext{
${ }^{111}$ Erhimbayar ("Mongolian Buddhist Monasteries," 191) has already noted that in the 2000s, the Yeke juu carried out few reforms to attract Han devotees.

${ }^{112}$ Fisher has pointed out the lack of interest that monastics take in the regulation of lay activities; they have little contact with lay Buddhists and do not consider it their responsibility to instruct them (Fisher, From Comrades to Bodhisattvas).
} 
Isabelle Charleux. Authors' own file, not the published version in Sino-Tibetan Buddhism across the Ages, Ester Bianchi \& Shen Weirong (dir.), Brill : Leyde \& Boston (Studies on East Asian Religious, vol. 5), 2021

makes it an exception among the frontier cities of the Qing period. ${ }^{113}$ Yet before the twentieth century, there was no religious mixing, only occasional cooperation between religious specialists.

Many changes occurred during the communist period, but Hohhot remains a particular case in Inner Mongolia. The Buddhist temples and monasteries are all located in its historical and touristic center. The Han Chinese and Mongol Buddhist inhabitants of Hohhot who need religious services converge on the narrow streets of the Old City where the Yeke juu and the Guanyinsi offer a variety of activities. The city's historical background in combination with the recent Tibetan Buddhist fever explains the resilience of the Yeke juu, which makes no real effort to attract Chinese devotees in a predominantly Chinese city.

Chinese Buddhism and Tibeto-Mongol Buddhism that, in the past, occupied clearly defined "religious ecological niches" 114 are now overlapping in Hohhot. Both the local authorities" "investments" and Han laypeople's sponsorship have led to increasing numbers of Chinese icons, steles, name plaques above entrances, decorations, and architectural characteristics within Mongol monasteries, but also to the introduction of Tibetan saints and wrathful deities into the iconographic program of the Guanyinsi. Although some of the jushis of the Guanyinsi are engaged in learning and practicing Buddhism, the majority of lay worshipers are more "traditional" devotees who make donations to either the Mongol or the Chinese Buddhist monasteries.

In the 1990s, Buddhism was tolerated yet not encouraged, and religious donations were seen as a "backward use" of money. In the late 1990s and 2000s, the Chinese state adopted a new attitude towards the officially recognized religions, which are no longer considered a hindrance to a modern, if tightly controlled, society. ${ }^{115}$ Buddhism has thus become an element of the state's soft power, with three major roles to play in modern society: tourism, ${ }^{116}$ morality, and ethnic harmony.

City authorities acknowledge the role of the monasteries in the public sphere because Buddhism contributes to the city's development and reciprocally. Monasteries can therefore be improved for many reasons - touristic exigencies, cultural symbols, and religious roles in urban modern society. The state is not the only actor in the rebuilding of monasteries. In the Old City of Hohhot, the new religious constructions that flourished after 2005 at the Mongol and the Chinese Buddhist monasteries were initiated and sponsored by both local governmental authorities and private donors - the majority of whom were Han businessmen. ${ }^{117}$ As in many other cases throughout China, the monastics complain that they were not actors in this

${ }^{113}$ Gaubatz, Beyond the Great Wall.

114 Ji \& Goossaert, "Introduction," 494.

115 The Chinese state's change in attitude toward religion, which has especially benefited Buddhism, was expressed during the 2006 and 2009 World Buddhism Forum (Ji, "Chinese Buddhism as a Social Force," 21). In exchange for this tolerance, Buddhism must support the Communist Party, contribute to the construction of a socialist China, and respect the rules. As expressed by Bulag, "the Party wants Buddhism to influence the people to support the Party" (Bulag, "Secularisation of Tibetan Buddhism," 37-39).

${ }^{116}$ On tourism and religion in China, see Oakes and Sutton, eds, Faiths on Display.

${ }^{117}$ As Ji Zhe and Vincent Goossaert have noted, "the Buddhist revival in the PRC results in large part from conflicts, negotiations and compromises between Buddhists (institutional religious authorities, individual spiritual masters, Buddhist associations), the state (state agents at various administrative levels), and numerous secular forces (lay businessmen, and intellectuals), each promoting their own specific interests" (Ji \& Goossaert, "Introduction," 492). 
Isabelle Charleux. Authors' own file, not the published version in Sino-Tibetan Buddhism across the Ages, Ester Bianchi \& Shen Weirong (dir.), Brill : Leyde \& Boston (Studies on East Asian Religious, vol. 5), 2021

rebuilding. ${ }^{118}$

The main reason for the local government to invest in temple (re)construction and protection and in the complete renovation of the Old City is to develop tourism. Tibetan (Mongol) Buddhism continues to be the official main religion of Hohhot because of the success of ethnic tourism. ${ }^{119}$ But as is stated above, Chinese Buddhism in Hohhot is supposedly not concerned with tourism. The city authorities' reasons for sponsoring the building of huge new halls at both the Yeke juu and the Guanyinsi are different; in the first case, it was to beautify the city's religious sites for tourists; in the second case, officially, it was because of the dangers posed by crowd movement in a small space. We can also deduce that city authorities and private sponsors of the Guanyinsi aimed to promote under-represented Chinese Buddhism on an equal footing with the Mongol monasteries. ${ }^{120}$ Tibetan Buddhism is deeply embedded in the social structure of the city, but the new construction has changed the relationship between the two Buddhist traditions, which are now more or less in the same league.

Second, Buddhism's moralistic and socially engaged precepts can be used to promote ethical behavior among citizens and cure the spiritual crisis (jingshen weiji 精神危机) experienced by stressed citizens who have felt the squeeze in the new market economy. This official discourse is clearly expressed in a 2005 article by Shuang Bao on the protection and development of the Mongol Buddhist monasteries of Hohhot: Tibeto-Mongol Buddhism is promoted to "let urban people evacuate their daily stress thanks to spiritual food." ${ }^{121}$ With their empty spaces, monasteries function as the lungs that allow the city to breathe and its people to clear away their daily stress. ${ }^{122}$

Third, in ethnically mixed cities such as Hohhot, Buddhism is viewed as a major factor of unity: it helps to promote inter-ethnic harmony, ${ }^{123}$ unity of nationalities (minzu tuanjie), ${ }^{124}$ and multiculturalism (duoyuan wenhua) at an official level. The multiculturality of the city is officially presented as a boon: the city promotes cultural and aesthetic mixing. For Shuang, the

\footnotetext{
${ }^{118}$ New construction projects and iconography are not decided by the abbot (which is mostly an honorific position) and the monastic community but by the "Democratic Management Committee" of the monastery (composed of monks and laypeople, some of whom are appointed by the Religious Affairs Bureau) with the approbation of the Religious Affairs Bureau.

${ }^{119}$ On the commodification of minority cultures in China, see Sutton \& Kang, "Recasting Religion and Ethnicity." Tourists (mostly Han) visit "unspoiled" minority areas (Tibet, Yunnan, or Inner Mongolia) that have retained a more "authentic" way of life. Their contact with the local populations is generally "filtered" by guides, tourist agencies, theme parks, and folk museums which present their exoticized culture in the manner of Western "human zoos." Their picturesque culture, reduced to a few easily isolable features, is staged in various performances (song and dance performances, tourist camps in the steppe). Although they derive little benefit from tourism, the Mongols themselves use the tourist industry as a space in which to express their own culture (Sanchez, "Making Mongols"). ${ }^{120}$ In 2007, the Inner Mongolia Autonomous Region had only fifty-one officially registered Chinese Buddhist monasteries and three Daoist monasteries ("Nei Menggu zizhiqu zongjiao gaishu," 2016).

121 "With the increasingly accelerating pace of urban life, urban people are always in a state of tension, fatigue, and a busy and restless atmosphere of life, which can lead to the psychological and mental illness that are widespread among contemporary urban people; and in the process of urbanization, Tibetan Buddhist culture may liberate contemporary urban people, be a spiritual food for bodies and minds that are in trouble... Tibetan Buddhism provides "purification and spiritual comfort... to modern people's minds"" (Shuang, "Chengshi fojiao simiao wenhua de baohu," 46).

${ }^{122}$ Shuang, "Chengshi fojiao simiao wenhua de baohu," 45.

${ }^{123}$ Cf. Hu Jintao's presidential motto of “a harmonious society” (hexie shehui 和諧社會), a political ideology that since 2005 has remained strong in the PRC as part of the continued development of China as a global economic leader.

124 The constructed notion of ethnic unity is also used to create "social harmony."
} 
religious festivals contribute to the enhancement of a communitas, a harmonious mixing (youjiao wulei 有教無類, religion without categories of ethnicity and social classes). ${ }^{125}$ But here Shuang speaks only of Mongol Buddhism; contemporary writings about religions in Hohhot tend to completely ignore Chinese Buddhism. "Tibetan (here meaning Mongol) Buddhism is the widely accepted public religion of Hohhot." ${ }^{\text {"Th }}$ This is a political claim. As we have seen, the negotiation of its place in Hohhot with other actors, notably lay Buddhists, evolves in different, sometimes contradictory ways.

\section{References}

\section{Sources}

“2010 nian Menggu fojiao wenhua gaoceng xueshu luntan zai Huhehaote juxing”2010年蒙古 佛教文化高層學術論壇在呼和浩特舉行, 14 March 2010. http://niis.cass.cn/xjdt/201003/t20100314_1997431.shtml, as of 2 November 2016.

“Baoerhan fota” 寶爾汗佛塔. http://baike.baidu.com/view/2570431.htm, as of 15 March 2016.

“Baoerhan ta qian gongdeng jinian fawang”寶爾汗塔前供燈紀念法王. http://www.baoerhan.com/, as of 15 March 2016.

“Baoerhan fota gongfeng zhuangcang shengwu zongti jieshao” 寶爾汗佛塔供奉裝藏聖物總 體介紹. http://www.baoerhan.com/Article/ShowArticle.asp?ArticleID=68, as of $15 \mathrm{March}$ 2016.

“Fahui-Huhehaote Guanyinsi juban 'Puxian yungong' baiwan gongdeng fahui” 法會—呼和 浩特觀音寺舉辦" 普賢雲供"百萬供燈法會，29 January， 2010. http://www.fjnet.com/fwzt/nr/201001/t20100129_146962.htm, as of 2 November 2016.

“Fahui一Huhehaote Guanyinsi juban sanshi xinian fahui (tu)” 法會一呼和浩特觀音寺舉辦三 時 繫 念法 會 ( 圖 ) , 29 January, 2010. http://www.fjnet.com/fwzt/nr/201001/t20100129_146964.htm, as of 2 November 2016.

“Fahui-Nei Menggu Huhehaote Dazhaosi longzhong juban ‘song baling' fahui” 法會一内蒙 古呼和浩特大召寺隆重舉辦“送巴令”法會 (6 March 2015, Nei Menggu zizhiqu fojiao xiehui 内蒙古自治區佛教協會). http://www.fjnet.com/fwzt/nr/201503/t20150306_228575.htm, as of 2 November 2016.

“Guanyinsi (Huhehaote)” 觀 音 寺 ( 呼 和浩特) https://zh.wikipedia.org/wiki/\%E8\%A7\%82\%E9\%9F\%B3\%E5\%AF\%BA_(\%E5\%91\%B C\%E5\%92\%8C\%E6\%B5\%A9\%E7\%89\%B9), as of 2 November 2016.

“Huhehaote Dazhaosi yinglai lüyou gaofengri jiedaiyouke jin 600 ren” 呼和浩特大召寺迎來 旅游高峰日接待游客近 600 人, 25 July 2008 .

\footnotetext{
${ }^{125}$ According to Shuang, people mix during festivals, share the same values (of compassion, shame, wealth), get to know each other, and form a society of devotees. It is a free religion with few requirements and interdictions ("Chengshi fojiao simiao wenhua de baohu," 46).

${ }^{126}$ Shuang, "Chengshi fojiao simiao wenhua de baohu," 46.
} 
Isabelle Charleux. Authors' own file, not the published version in Sino-Tibetan Buddhism across the Ages, Ester Bianchi \& Shen Weirong (dir.), Brill : Leyde \& Boston (Studies on East Asian Religious, vol. 5), 2021

http://www.fjnet.com/shxx/shxxnr/200807/t20080725_77568.htm, as of 2 November 2016.

“Huhehaote fojiaojie zizhu 6 ming xinsheng shang daxue”呼和浩特佛教界資助6名新生上 大學, 22 August 2012. http://news.wenweipo.com/2012/08/22/NN1208220043.htm, as of 2 November 2016.

“Huhehaote Guanyinsi-Guanyinsi jianjie” 呼和浩特觀音寺一觀音寺簡介. http://www.baike.com/wiki/\%E5\%91\%BC\%E5\%92\%8C\%E6\%B5\%A9\%E7\%89\%B9\% E8\%A7\%82\%E9\%9F\%B3\%E5\%AF\%BA\&prd=button_doc_jinru, as of 2 November 2016.

“Huhehaote guji daguimo xiushan yingjie xiaji lüyou re” 呼和浩特古跡大規模修縉迎接夏季 旅游熱, 5 May 2007. http://news.sohu.com/20070505/n249854075.shtml, as of 2 November 2016.

“Huhehaoteshi Dazhaosi huanqing randengri”呼和浩特市大召寺歡慶燃燈日, 6 December, 2015. http://www.nmgfx.cn/index/article/index/274, as of 2 November 2016.

“Huhehaoteshi Dazhaosi juban randengjie fahui” 呼和浩特市大召寺舉辦燃燈節法會, 17 December 2014. http://www.nmgfx.cn/index/article/index/177, as of 2 November 2016.

“Huhehaoteshi Dazhaosi mani fahui yuanman jieshu”呼和浩特市大召寺嘛呢法會圓滿結束, 21 September 2016. http://www.nmgfx.cn/index/article/index/354, as of 20 February 2016.

“Huhehaoteshi fuyuan Qingdai mingsi-Cidengsi”呼和浩特市復原清代名寺——慈燈寺, 12 July 2006. http://www.nmg.xinhuanet.com/xwzx/2006-07/12/content_7500453.htm, as of 2 November 2016.

“Huhehaote zhongduo guji daguimo xiushan yingjie xiaji lüyou re” 呼和浩特眾多古跡大規 模修繕迎接夏季旅游熱, 5 May 2007. http://www.foyuan.net/article-23044-1.html, as of 2 November 2016.

“Hushi yuji mingnian shang bannian jiangzai Dazhao jiancheng Yufodian” 呼市預計明年上 半年將在大召建成主佛殿, 28 June 2006. http://www.fjdh.cn/bnznews/2006/06/2114154700.html, as of 2 November 2016.

“Hushi zongtouzi 3000 yu wan yuan kuojian Dazhao Guanyinmiao” 呼市總投資3000余萬元 擴 建 大 召 觀 音 廟 ， 7 June 2006. http://news.sina.com.cn/c/2006-0607/171510093681.shtml, as of 2 November 2016.

“Jiangzuo-Huhehaote Guanyinsi Chenghuan fashi wei sizhong dizi xuanjiang faben” 講座— 呼和浩特觀音寺澄還法師為四眾弟子宣講法本, 11 January 2010. http://www.fjnet.com/fwzt/nr/201001/t20100111_145622.htm, as of 2 November 2016.

“Longduo Danzengrongbo huofo lishi yinghua jianjie” 龍多.丹增榮波活佛曆世應化簡介, 15 November 2008. http://www.baoerhan.com/cggs/ShowArticle.asp?ArticleID=70, as of 15 March 2016.

“Nei Menggu Huhehaoteshi Taiqinggong caijing”內蒙古呼和浩特市太清宫彩影, 12 November 2007. http://nmgtaiqinggong.blog.sohu.com/70202831.html, as of 15 March 2016.

“Nei Menggu Huhehaote Xilituzhao huofo jianlüe” 內蒙古呼和浩特席力圖召活佛簡略, 15 December 2015. http://www.douban.com/note/529134383/, as of 2 November 2016. 
“Nei Menggu Hushi Guanyinsi (http://guanyinsi.fjnet.com/) kaitong” 內蒙古呼市觀音寺 (http://guanyinsi.fjnet.com/) 開通, 20 May 2010.

“Nei Menggu zizhiqu zongjiao gaishu” 內蒙古自治區宗教概述， 2016. http://www.nmqq.gov.cn/minzuzongjiao/ShowArticle.asp?ArticleID=20996, as of 2 November 2016.

“Shijie diyi fota: Baoerhan fota”世界第一佛塔——寶爾汗佛塔, 20 October 2009. http://bbs.zol.com.cn/dcbbs/d1061_25173.html

(and http://www.articleswriting.net/article/3858740515/), as of 2 November 2016.

““Xian aixin song wennuan cishan juanzhu huodong’ zai Huhehaoteshi Dazhaisi zhaokai” “獻 愛心送溫暖慈善捐助活動”在呼和浩特市大召寺召開, 20 January 2016. http://www.nmgfx.cn/index/article/index/291, as of 2 November 2016.

Wikipedia, "Hohhot." https://en.wikipedia.org/wiki/Hohhot\#Administrative_divisions, as of 2 November 2016.

“(Yuan chuang) Hushi weiyi de hanchuan simiao-Guanyinsi”（原創）呼市唯一的漢傳寺 廟—觀音寺. http://shaonianyou.lofter.com/post/b37c8_62f3bad, as of 2 November 2016.

Zheng Yufu 鄭裕孚 \& Zheng Zhichang 鄭植昌, Guisui xian zhi 歸綏縣志, Beijing, 1934. Ed. Taipei: Chengwen chubanshe, 1968 (Zhongguo fangzhi congshu, Saibei difang, 10).

\section{Secondary literature}

Atwood, Christopher P. 1994. "National Questions and National Answers in the Chinese Revolution; or How Do You Say Minzu in Mongolian?" Indiana East Asian Working Paper Series on Language and Politics in Modern China 5: 36-73.

Bao Muping 包慕萍. 2005. Mongoru ni okeru toshi kenchikushi kenkyū: Yūboku to teijū no jūsō toshi fufuhoto モンゴルにおける都市建築史研究: 遊牧と定住の重層都市フフホ 卜. Tokyo: Tōhō Shoten 東方書店.

Bianchi, Ester. 2014. “A Religion-Oriented 'Tibet Fever.' Tibetan Buddhist Practices Among the Han Chinese in Contemporary PRC." In Dramdul and F. Sferra, eds., 347-74; From Mediterranean to Himalaya. A Festschrift to Commemorate the 120th Birthday of the Italian Tibetologist Giuseppe Tucci一从地中海到喜马拉雅: 意大利著名藏学家朱塞佩

·图齐诞辰120 周年纪念文集 (Beijing: China Tibetology Publishing House).

2018. "Teaching Tibetan Buddhism in Chinese on Behalf of Mañjuśrī: 'Great Perfection' (dzok chen / dayuanman 大圓滿) and Related Tantric Practices among Han Chinese and Taiwanese Believers in Sertar and Beyond." In Fabienne Jagou, ed., 109-31; The Hybridity of Buddhism. Contemporary Encounters between Tibetan and Chinese Traditions in Taiwan and the Mainland (Paris: École française d'Extrême-Orient).

Bilik, Naran. 1998. "The Mongol-Han Relations in a New Configuration of Social Evolution." Central Asian Survey 17/1: 69-91.

Billé, Franck. 2009. "Cooking the Mongols/Feeding the Han: Dietary and Ethnic Intersections in Inner Mongolia." Inner Asia 11/2: 205-30. 
Isabelle Charleux. Authors' own file, not the published version in Sino-Tibetan Buddhism across the Ages, Ester Bianchi \& Shen Weirong (dir.), Brill : Leyde \& Boston (Studies on East Asian Religious, vol. 5), 2021

Birnbaum, Raoul. 2003. "Buddhist China at the Century's Turn." The China Quarterly 174 (Religion in China Today): 428-50.

Bulag, Uradyn E. 1996. "Secularisation of Tibetan Buddhism in Contemporary China. Views of the Ajia Rimpoche of Kumbum Monastery." Inner Asia (Occasional papers of the Mongolia and Inner Asia Studies Unit), 1/1: 24-42.

. 1999. "Models and Moralities: The Parable of the Two 'Heroic Little Sisters of the Grassland." China Journal 42: 21-41.

- 2010. Collaborative Nationalism: The Politics of Friendship on China's Mongolian Frontier. Lanham: Rowman \& Littlefield Publishers (Asia/Pacific/Perspectives).

2010 [2000]. "Alter/native Mongolian Identity. From Nationality to Ethnic Group.” In Elizabeth J. Perry and Mark Selden, eds., 261-87; Chinese Society. Change, Conflict and Resistance (London and New York: Routledge).

Charleux, Isabelle. 2003. "The Reconstruction of Buddhist Monasteries in the Chinese Autonomous Region of Inner Mongolia: Between Sanctuary and Museum." Paper given at The International Conference "Revival of Buddhism in Mongolia after 1990" (Warsaw, 24-28 ${ }^{\text {th }} \quad$ November 1999) (online: https://halshs.archives-ouvertes.fr/halshs01377313/document).

2004. "De la ville bleue à la métropole grise. Fondation, protection et destruction de Kökeqota (Huhehaote).” Études mongoles et sibériennes 35: 69-116.

. 2006. Temples et monastères de Mongolie-Intérieure. Paris: Comité des Travaux Historiques et Scientifiques \& Institut National d'Histoire de l'Art (+ 1 CD rom).

. 2011. "Kangxi/Engke Amuyulang, un empereur mongol? Sur quelques légendes mongoles et chinoises." Études mongoles et sibériennes, centrasiatiques et tibétaines 42. Online: http://emscat.revues.org/index1782.html

2015. "The Mongols' Devotion to the Jowo Buddhas: The True Icons and their Mongol Replicas." Artibus Asiae 75/1: 83-146.

Chen, Bing. 2008. "The Tantric Revival and its Reception in Modern China." In Monica Esposito, ed., vol. 2, 387-42; Images of Tibet in the 19th and 20th Centuries (Paris: École française d'Extrême-Orient).

Erhimbayar. 2006. "Mongolian Buddhist Monasteries in Present-day Northern China a Comparative Study of Monasteries in Liaoning and Inner Mongolia.” Inner Asia 8/2: 183203.

Fisher, Gareth. 2014. From Comrades to Bodhisattvas. Moral Dimensions of Lay Buddhist Practices in Contemporary China. Honolulu: University of Hawai'i Press.

Gaubatz, Piper Rae. 1996. Beyond the Great Wall. Urban Form and Transformation on the Chinese Frontiers. Stanford: Stanford University Press.

Gladney, Dru C. 1994. "Representing Nationality in China: Refiguring Majority/Minority Identities." Journal of Asian Studies 53/1: 92-123.

Humphrey, Caroline and Hurelbaatar Ujeed. 2013. A Monastery in Time. The Making of Mongolian Buddhism. Chicago and London: University of Chicago Press.

Hyer, Paul. 1982. "An Historical Sketch of Köke-Khota, City Capital of Inner Mongolia.” 
Isabelle Charleux. Authors' own file, not the published version in Sino-Tibetan Buddhism across the Ages, Ester Bianchi \& Shen Weirong (dir.), Brill : Leyde \& Boston (Studies on East Asian Religious, vol. 5), 2021

Central Asiatic Journal 26/1-2: 56-77.

Jankowiak, William. 1993. Sex, Death and Hierarchy in a Chinese City. An Anthropological Account. New York: New York University Press.

Ji, Zhe. 2012. "Chinese Buddhism as a Social Force." Chinese Sociological Review 45/2: 8-26.

Ji, Zhe and Vincent Goossaert. 2011. "Introduction: Social Implications of the Buddhist Revival in China." Social Compass 58: 491-97.

Jones, Alison Denton. 2011. "Contemporary Han Chinese Involvement in Tibetan Buddhism: A Case Study from Nanjing." Social Compass 58/4: 540-53.

Khan, Almaz. 1996. "Who Are the Mongols? State, Ethnicity and the Politics of Representation in the People's Republic of China." In Melissa Brown, ed., 125-59; Negotiating Ethnicities in China and Taiwan (Berkeley: Institute of East Asian Studies, University of California).

Laliberté, André. 2012. "Buddhist Charities and China's Social Policy: An Opportunity for Alternate Civility?” Archives de Sciences Sociales des Religions 158: 95-117.

Maags, Christina and Marina Svensson (dir.). 2018. Chinese Heritage in the Making: Experiences, Negotiations and Contestations. Amsterdam: Amsterdam University Press \& IIAS.

MacInnis, Donald E. 1989. Religion in China Today: Policy and Practice. Maryknoll (New York): Orbis Books.

Mair, Jonathan. 2012. "Cultures of Belief.” Anthropological Theory 12/4: 448-66.

. 2013. "Rebirth Control: Contemporary Inner Mongolian Buddhism and the Religious Authority of the Chinese State." In John Whalen-Bridge and Pattana Kitiarsa, eds., 21617; Buddhism, Modernity, and the State in Asia: Forms of Engagement (New York: Palgrave Macmillan).

Oakes, Tim and Donald S. Sutton (eds) 2010. Faiths on Display: Religion, Tourism and the Chinese State. Lanham: Rowman \& Littlefield.

Sanchez, Jamie N. 2016. "Making Mongols: Representations of Culture, Identity, and Resistance.” PhD. Diss., Faculty of the Virginia Polytechnic Institute and State University.

Shepherd, Robert. 2006. "UNESCO and the Politics of Cultural Heritage in Tibet." Journal of Contemporary Asia 36/2: 243-257.

Shepherd, Robert J. and Larry Yu. 2013. Heritage Management, Tourism, and Governance in China. New York: Springer.

Shuang Bao 雙寶. 2015. “Chengshi fojiao simiao wenhua de baohu yu kaifa wenti chuyi-yi Huhehaote shi zangchuan fojiao simiao wei lunshu zhongxin”城市佛教寺廟文化的保護 與開發問題㫚議—以呼和浩特市藏傳佛教寺廟為論述中心. Yinshan xuekan 陰山學 刊 4: 43-47.

Smyer Yü, Dan. 2012. The Spread of Tibetan Buddhism in China. Charisma, Money, Enlightenment. London and New York: Routledge.

Stockwell, Foster. 1993. Religion in China Today. Beijing: New World Press.

Sutton, Donald and Xiaofei Kang. 2009. "Recasting Religion and Ethnicity: Tourism and Socialism in Northern Sichuan, 1992-2005." In Thomas David DuBois, ed., 190-214; 
Casting Faiths: The Construction of Religion in East and Southeast Asia (London: Palgrave Macmillan).

Tam, Lui. 2018. "The Revitalization of Zhizhu Temple Policies, Actors, Debates." In Christina Maags and Marina Svensson (eds), 245-268; Chinese Heritage in the Making: Experiences, Negotiations and Contestations.

Tang Jisi 唐吉思. 2009. “Mengguzu diqu fojiao fazhan de tedian ji jiben quxiang”蒙古族地 區佛教發展的特點及基本趋向. In Di sanjie liang'an sidi fojiao xueshu yantaohuiXueshu lunwenji 第三屆兩岸四地佛教學術研討會一學術論文集, 185-91 (Beijing: Zhongyang minzu daxue, 18-20 December 2009).

Terrone, Antonio. 2012. "Messengers from Tibet's Past: The Role of Buddhist Charismatic Leaders in the Spread of Tibetan Buddhism in Contemporary China." Asiatica Ambrosiana 4: 103-21.

Yang Jiaming 楊嘉銘. 2005. “Nei Menggu zangchuan fojiao jinkuang zhi tantao” 內蒙古藏傳 佛教近況之探討. MengZang xiankuang shuangyue bao 蒙藏現況雙月報 14/6: 1-25.

Zhamusu 扎木蘇. 1997. “Wo de huofo shengya”我的活佛生涯 (interview of Zhamusu by Wuyun Gaoya 烏雲高娃/ Oyunguu-a). In Nei Menggu lamajiao jili 內蒙古喇嘛教紀例, 258-64 (Hohhot: Nei Menggu wenshi shudian). 